\title{
THE TOXIC CONSTITUENT OF RICHWEED OR WHITE SNAKEROOT (EUPATORIUM URTICAEFOLIUM)
}

BY

\section{JAMES FITTON COÚCH}

(Contribution from Bureau of Animal Industry)

Reprinted from JOURNAL OF AGRICULTURAL RESEARCH

Vol. 35, No. 6 : : : : Washington, D. C., September 15, 1927

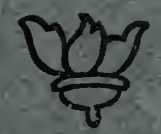

PUBLISHED BY AUTHORITY OF THE SECRETARY OF AGRICULTURE WITH THE COOPERATION OF THE ASSOCIATION OF LAND-GRANT COLLEGES AND UNIVERSITIES 


\section{JOINT COMMITTEE ON POLICY AND MANUSCRIPTS}

\section{FOR THE UNITED STATES DEPARTMEN} OF AGRICULTURE

E. W. ALIEN, ChatrMin

Chie\}, Ofice of Experiment Station.

C. L. SHEAR

Senior Pathologist in Charge, Mycology and Disease Survey

A. C. BAKER

Senior Entomologist in Charge, Tropical and Subtropical Plant Insect Inviestigationis
FOR THE ASSOCIATION OF LAND-GRANT COLLEGES AND UNIVERSITIES

R. W. THATCHER

Director, New X ork Experiment Stations

S. B, HASKELL

Director; Massachusetts Experiment Station

M. J. FUNCHESS

Director. Alaboma Experiment Station

\section{EDITORIAL SUPER VISION}

M. C. MERRILI,

Editorial Chief of Publications, United States Department of A griculture

A11 correspondence regarding articles from State experiment stations should be addressed to R. W. Thatcher, Agricultural Experiment Station, Geneva, N. Y:

Published on the first and fiftcenth of each month. This yolume will consist of twelve numbers and the Contents and Index.

$$
\begin{aligned}
\text { Subscription price: } & \text { Domestic, } \$ 4.00 \text { a year (two volumes) } \\
& \text { Single numbers, } 20 \text { cents } \\
& \text { Foreign, } \$ 5.00 \text { a year (two yohmes) } \\
& \text { Single numbers, } 25 \text { cents }
\end{aligned}
$$

If separates are desired in quantity, they should be ordered at the time the manuscript is sent to the printer, and they will be supplied practically at cost. Single copies of separates may be obtained free of charge from the Office of Information, United States Department of Agriculture, until the supply is exhausted.

Address all correspondence regarding subscriptions and purchase of numbers and separates to the Superintendent of Documents, Government Printing Office, Washington, D. C. 


\title{
THE TOXIC CONSTITUENT OF RICHWEED OR WHITE SNAKEROOT (EUPATORIUM URTICAEFOLIUM) ${ }^{1}$
}

\author{
By James Fitton Couch \\ Pathological Division, Bureau of Animal Industry, United States Department of \\ Agriculture
}

\section{HISTORICAL REVIEW}

Among the many perils and hardships that marked the settlement of the old frontier of the United States was the mysterious malady known as "milk sickness." Appearing customarily late in the summer it rapidly assumed epidemic proportions, sparing neither age nor sex, frequently sweeping away a quarter of the population, and sometimes depopulating whole villages. Nearly every district in the old West-now the Central West-suffered at one time or another from this disease and so sudden was its onset, so recondite its cause, so unavailing were the preventive measures taken by the terrified backwoodsmen, and so fatal were the attacks, that the old chroniclers refer to it in the strongest terms as formidable, terrible, and frightful. Nicolay and Hay $(17)^{2}$ describe a characteristic outbreak during which the mother of Abraham Lincoln died.

In the autumn of 1818 the little community of Pigeon Creek was almost exterminated by a frightful pestilence called the milk sickness, or, in the dialect of the country, "the milk sick." It is a mysterious disease ... It seems to have been a malignant form of fever-attributed variously to malaria and to the eating of poisonous herbs by the cattle - attacking cattle as well as human beings, attended with violent retching and a burning sensation in the stomach, often terminating fatally on the third day. In many cases those who apparently recovered lingered for years with health seriously impaired.

The disease was known in Maryland, North Carolina, Kentucky, Tennessee, Alabama, Missouri, Illinois, Indiana, and Ohio from the time of the early settlements. Wolf, Curtis, and Kaupp (22) in one of the most complete accounts of this sickness that has ever been published, have shown that milk sickness was recognized as a particular disease in North Carolina before the Revolution. The early settlers were also acquainted with a disease of cattle known as "trembles" that appeared only in "milk-sick areas" and during the same periods in which human milk sickness was prevalent. It was observed, too, that suckling calves frequently sickened and died from "trembles" in these same milk-sick areas and that small domestic animals, pigs, cats, and dogs, fed on the milk of cows that were permitted to range the woods, developed symptoms of nausea, weakness, and enteritis, and died. These facts led to the suspicion that the milk of cows at certain seasons contained some deleterious substance that was capable of causing milk sickness in human beings who drank it or ate butter and cheese made from it. This idea was further strengthened by the fact that those who prudently abstained from all bovine products late in summer and fall were free from attacks of

1 Received for publication May 12, 1927; issued November, 1927.

2 Reference is made by number (italic) to "Literature cited," p. 575.

Journal of Agricultural Research,

Washington, D. C.

Vol. 35, No. 6

Sept. 15,1927

Key No. A-120 
milk sickness and that those who discontinued eating milk products as soon as they began to sicken with the disease generally recovered after suffering merely a slight illness.

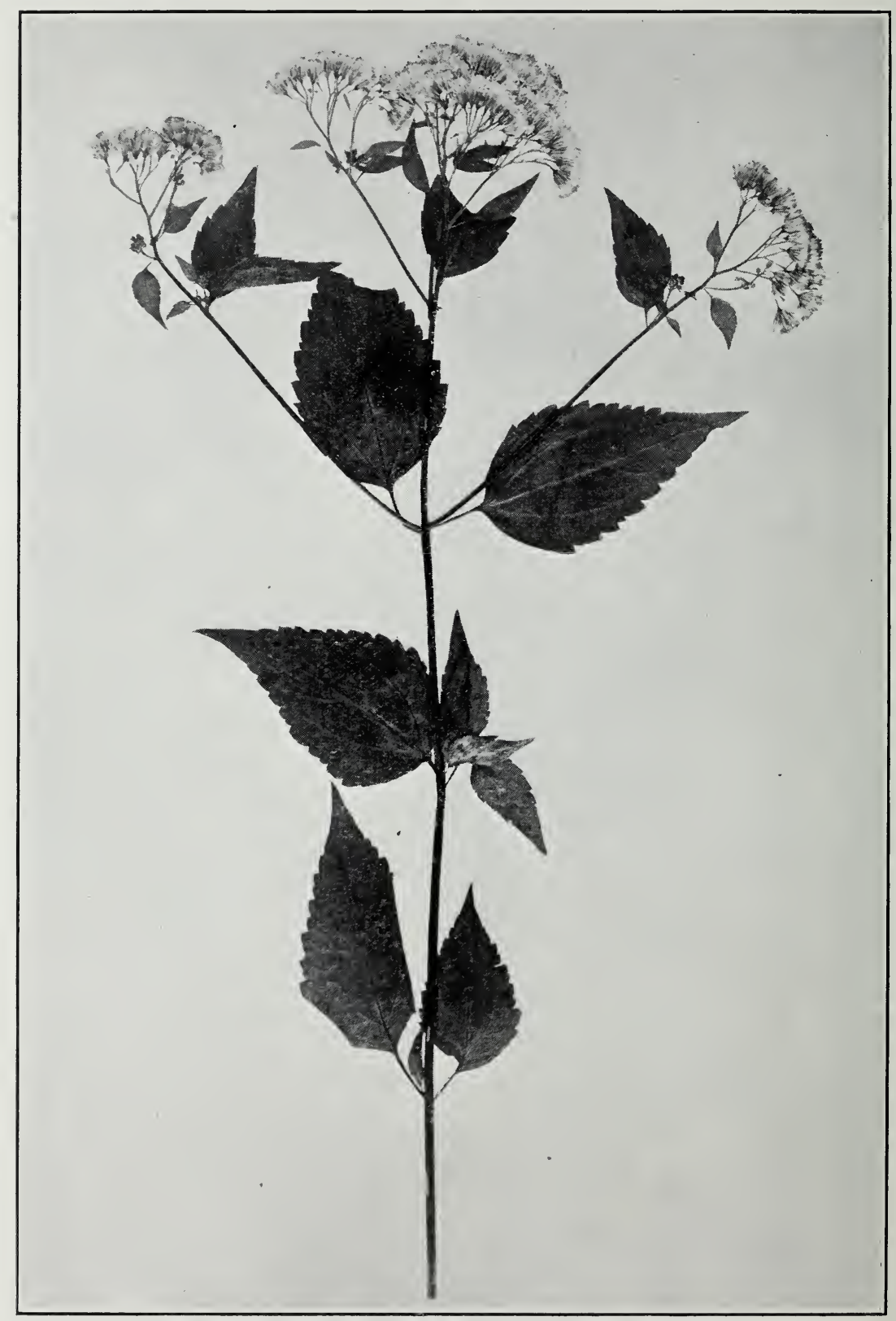

FIG. 1.-Richweed or white snakeroot (Eupatorium urticaefolium)

The nature of the deleterious substance present in this poisonous milk remained obscure. Speculation as to its character was widespread and resulted in the advancement of many fantastic ideas. 
Poisonous dew and volatile minerals that evaporated from the earth at night, condensing on the herbage, there to await ingestion by the grazing herds, miasmata, the early conception of a germ theory, microorganisms, various poisonous minerals, arsenic, copper, lead, cobalt, as well as poisonous springs, all were advanced as explanations of the origin of the scourge. By far the most favored theory, however, and one held tenaciously from the earliest times was that milk sickness was caused by the feeding of the cows on some weed or herb that could transmit poisons to the milk. This hypothesis was strengthened by a large number of observed facts. The disease was most virulent late in summer and early fall, particularly after a period of drought, when wholesome forage plants had been consumed and the cattle were compelled to graze on plants that they refused when other feed was plentiful. Again, cattle that were pastured in inclosed fields where weed infestation was slight did not contract the trembles nor did their milk cause milk sickness. It was observed that the incidence of milk sickness diminished as the forests were cleared and the land brought under cultivation. Many different plants were suspected to be the cause. Some of them, such as poison ivy, water hemlock (Cicuta maculata), "Indian hachy," Indian tobacco (Lobelia inflata), Indian hemp (Apocynum cannabinum), Virginia creeper (Parthenocissus quinquefolia), cross vine (Bignonia capriolata), Indian currant (Symphoricarpos orbiculatus), marsh marigold (Caltha palustris), spurge (Euphorbia esula), fool's parsley (Arethusa cynapium), mushrooms, and richweed (Eupatorium urticaefolium) were well known as poisonous plants. Others argued in favor of the modified hypothesis that the disease was caused by parasitic fungi or by molds that grew on various plants.

The last-named plant, Eupatorium urticaefolium, known commonly as richweed, white snakeroot, pool wort, pool root, white sanicle, Indian sanicle, deer wort, squaw weed, white top, and steria, has been most widely and commonly held responsible for the disease. A great many experiments have been made in which this plant has been fed to animals with the result that trembles has been produced in a large number of cases. In recent years a mass of proof has been obtained to show that the plant is poisonous to livestock and that suckling animals may be poisoned by the milk secreted by animals that have eaten it.

Notwithstanding the many evidences of the poisonous nature of richweed and the many indications of its connection with human milk sickness, some observers have doubted its relation either to trembles or to milk sickness, and have advanced very strong arguments against the conclusion. They have pointed out that cattle have been known to graze for long periods in places where richweed grows abundantly without the appearance of any cases of trembles in the cattle or of milk sickness in the people who drank their milk. They further contended that in many of the feeding experiments the animals failed to develop abnormal symptoms. Finally, it was discovered that a disease resembling trembles in cattle and milk sickness in human beings exists in certain places in New Mexico and Texas where richweed is not found.

It is quite true that cattle have been known to graze with impunity in pastures infested with richweed, but it is also true that stock do not voluntarily eat this plant so long as other forage is available; 
and the mere presence of richweed in a pasture does not prove that it has been eaten by the animals confined there.

Failure to produce the disease by feeding the plant is inconclusive evidence unless supported by a thorough and systematic course of experiments. One feeding of Eupatorium urticaefolium, unless in very large quantity, would certainly fail to provoke symptoms of trembles, and the result of such a feeding may lead to an uncritical opinion that the plant is harmless. Feeding of dried or partly dried plant would also fail to produce the disease in many if not in all cases. Furthermore, it is by no means certain that there is not a variation in the toxicity of richweed at different seasons or in different years or in plants from different localities.

The discovery of endemic milk sickness in the Pecos Valley of New Mexico, where Eupatorium urticaefolium does not grow, was considered strong evidence against the conclusion that richweed caused that disease. It has been shown, however, by a number of investigators that milk sickness and trembles in New Mexico are caused by the rayless goldenrod, Aplopappus heterophyllus (A. Gray) (Blake), also termed Isocoma wrightii, Isocoma heterophylla, Bigelovia rusbyi, and Bigelovia wrightii.

The theory that milk sickness is due to some specific microorganism has been held by several observers (11). Jordan and Harris (9), in a very careful and detailed examination of the possibility of pathogenic microorganisms being the cause of the disease, isolated a bacillus that appeared to be a possible solution to the problem. This organism they named Bacillus lactimorbi and they made an extensive study of it. At the end of their research, however, they candidly stated $(9, p .484-485)$ :

"Taken as a whole the facts do not surely indicate that a specific microorganism is the cause of milk sickness or trembles."

The work of Jordan and Harris was supplemented by a bacteriological study of their organism by Luckhardt (10) in which various strains of the organism fed by him to dogs did not produce typical trembles. In pathogenicity the organism was very erratic. Luckhardt found it very widespread and growing on plants, such as alfalfa, that have never been associated with milk sickness. His study was, as he says, "far from being decisive in establishing $B$. lactimorbi as the etiological factor in the production of milk-sickness."

At the present time the only hypothesis that has any standing is that richweed poisoning causes this disease in the East. All the experimental work reported in the last decade supports this point of view and demonstrates that Eupatorium urticaefolium is a distinctly poisonous plant and that milk obtained from cows that have fed on it is capable of producing the disease in other animals.

Full descriptions of the history and characteristics of the disease have been published $(11,8,2,18,22)$.

Apparently the first published account of milk sickness was included by Daniel Drake (4), who published the information concerning the disease that Barbee, of Virginia, collected while visiting the Mad River country of Ohio, in 1809, and other data gathered by Drake himself. In a larger work (5) Drake again notices the milk sickness and mentions the fact that some ascribe it to the poison of some unknown plant that is secreted in cow's milk. Meanwhile 
"Liberty Hall" (6) had published the case of Alex. Telford and family in which the milk from four cows was strongly suspected of causing the outbreak.

A great deal has been written about milk sickness in the medical journals and considerable controversial material has developed in which even the existence of the disease as a specific malady has been denied. Some cursory experiments were made to determine the toxic properties of richweed but they were often of such a nature as to yield little positive knowledge.

About 20 years ago Moseley (13) reported a series of experiments with laboratory animals that indicated toxic properties in richweed. Crawford (2) reviewed the work, made some experiments, and concluded that there is no relationship between richweed and milk sickness. The distinctly poisonous nature of the plant, however, was demonstrated beyond question by a series of researches published during the last 10 years by Curtis and Wolf (3), who showed that the disease was not infectious; by Marsh and Clawson (12); Wolf, Curtis, and Kaupp (22), who poisoned animals on the sap of the plant; and by Sackett (19), who was able to poison laboratory animals with extracts of the plants. The results of Sackett's experiments further confirmed the toxic character of richweed.

When the writer began the study of this subject in 1918, the principal problem to be solved was the isolation of the toxic constituent and the elucidation of its chemical properties.

\section{PREVIOUS CHEMICAL INVESTIGATIONS OF RICHWEED}

No complete chemical analysis has yet been made of the whole plant of Eupatorium urticaefolium, although a number of investigators in the course of studies of the toxic constituent, have made extracts of the plant and have fed these to animals.

Moseley (13) fed extracts of the plant in water and milk to rabbits and dogs, and also gave parts of the plant to these animals. Crawford (2) injected aqueous extracts subcutaneously into two rabbits which died and into three others which survived. These extracts were made from dried plants. Extracts from plants preserved in chloroform water failed to injure a cat, a dog, a sheep, and Crawford himself, when fed in small dosage. Injection of the ash, obtained from 10 and $20 \mathrm{gm}$. of dried plant and neutralized with acetic acid, into rabbits, did not produce poisoning.

In 1909 Moseley (14) published his conclusions that the toxic constituent of richweed is aluminum phosphate, and adduced experimental evidence in support of this hypothesis. In 1910 Moseley (15) published further evidence to support the aluminum phosphate hypothesis, and advocated the use of soda as an antidote.

Curtis and Wolf (3) fed aluminum phosphate in doses of from 2 to $16 \mathrm{gm}$. to two ewes during a period of 69 days, at the expiration of which each had received $412 \mathrm{gm}$. of the compound. Neither of the ewes developed any abnormal symptoms and each gained weight.

Mosely (16) withdrew the aluminum phosphate hypothesis in favor of the conclusion that an "ether soluble resin" is the toxic principle. He reported that he obtained 9 per cent of the dry weight of the leaves by extracting with ether and that nearly all the extract 
was resin. He does not record his experiments but states that the resin poisons cats, rabbits, and guinea pigs like Eupatorium.

Wolf, Curtis, and Kaupp (22) in an excellent monograph describe the most extensive use of extracts that had appeared up to that time. Aqueous and alcoholic extracts fed by them to guinea pigs did not produce poisoning. One of three guinea pigs to which they fed hydrochloric acid extract died. The expressed juice of fresh plant was fed to five guinea pigs, four of which died. Dried extract from the sap prepared by exsiccation on a water bath at $100^{\circ} \mathrm{C}$. did not affect three guinea pigs to which it was fed. The volatile matters from the sap fed to three guinea pigs did not affect the animals. The inspissated juice evaporated at a temperature less than $60^{\circ} \mathrm{C}$. fed to three guinea pigs caused the death of one. The other two merely showed some depression. Five sheep were fed the expressed juice of richweed and died with symptoms of trembles; two sheep were fed inspissated juice evaporated at a temperature below $60^{\circ} \mathrm{C}$. and died with symptoms of trembles; and a sheep was fed the nonvolatile portions of the juice and developed trembles and died. These investigators were able to produce trembles in two out of six suckling lambs by feeding richweed to the mothers. A sample of "milk-sick" butter was fed to three mice, two of which died. Seven dogs were fed meat from trembles cases and showed no ill effects. As a result of these experiments the investigators concluded that the toxic constituent of richweed is glucosidal. In all their experiments they used green plant collected at Shooting Creek, N. C.

A valuable contribution to the subject was made by Sackett (19), who conducted many experiments with extracts from the leaves of Eupatorium urticaefolium on rabbits and guinea pigs. Fresh and carefully dried leaves and alcohol and chloroform ether-ammonia (Prolius's solution) extracts of richweed fed by him produced poisoning in animals. The alcohol and Prolius's solution marcs were nontoxic as were the extracts made with salt solution and that from the roots. Viscera and meat from a rabbit killed by richweed poisoning did not affect a cat. An anaphylactic experiment was negative. Guinea pigs were not affected by the dried leaves.

Jordan, Whelan, and Gidley (7) made some experiments with extracts from dried plants collected in Indiana. These were fed to rabbits and the marc from a 0.1 per cent hydrochloric acid extraction was fed to a hen. The 50,70, and 95 per cent alcohol extracts, an ether-chloroform extract, and the extract made with a menstruum of 50 per cent alcohol and 0.5 hydrochloric acid were nontoxic. A 0.5 per cent hydrocloric acid extract killed a rabbit in four hours. A 0.1 per cent hydrochloric acid extract was fed to a rabbit which died in three days; the marc from this fed to a hen produced no effect. A similar 0.1 per cent hydrochloric acid extract which had fermented produced no result when fed to a rabbit. The resin was nontoxic.

These investigators report that there is neither alkaloid nor glucoside in the plant.

Bukey (1) reported a partial analysis of the fruit of Eupatorium urticaefolium, which includes data concerning a drying oil that he extracted, together with a proximate analysis of the other constituents. 
From this contradictory mass of data it may be concluded that: The toxic principle appears to be soluble in alcohol, ether, and chloroform, and insoluble in water; it is apparently nonvolatile and is destroyed or greatly weakened by drying the plant; it appears to be thermostable within reasonable limits; nothing is certain about its chemical characters.

\section{THE PRESENT INVESTIGATION}

The result of the present investigation has been the isolation of a definite, toxic substance from green Eupatorium urticaefolium which appear's capable of producing the characteristic symptoms of trembles in sheep and of a second toxic substance, not yet obtained in a pure condition, which is toxic to guinea pigs but does not affect sheep even in very large doses and probably has no relationship to milk sickness.

\section{TREMETOL}

The substance which appears to be responsible for trembles is a viscous, oily liquid of pleasant, aromatic odor which does not solidify at very low temperatures and can not be made to crystallize. Analysis and molecular-weight determinations indicate that the formula of this substance is $\mathrm{C}_{16} \mathrm{H}_{22} \mathrm{O}_{3}$. It has been named tremetol from tremere, to tremble, inasmuch as all feasible names derived from the generic name of the plant have already been used to designate other substances. Tremetol has the characters of an alcohol; the hydroxyls are not phenolic and alkoxyl groups appear to be absent. It does not react with hydroxylamine or with phenylhydrazine to form crystalline substances, nor does it give color reactions with Schiff's reagent or with ferric chloride. It withstands the temperature of boiling water but is rapidly decomposed when attempts to distill it are made, even at pressures below $1 \mathrm{~mm}$. It is very slowly volatile with steam. It is soluble in petroleum ether, ether, chloroform, alcohol, and benzene, and quite insoluble in water, acids, or alkaline solutions.

It is levorotatory in alcoholic solution, $[a] \frac{20}{D}=-21.08^{\circ}$. It absorbs four atoms of bromine, which indicates the presence of two double bonds.

Potassium permanganate oxidizes it to a crystalline acid that melts at $181^{\circ} \mathrm{C}$. Tremetol apparently exists in the plant partly in ester combination with a resinous acid, the chemistry of which is still being studied. The toxic substance may be prepared by the following method.

\section{Method of Preparing Tremetol}

To obtain tremetol the fresh richweed plant is hashed through a meat chopper and immediately packed in a percolator with strong alcohol, macerated two days and then percolated to exhaustion with strong alcohol. The solvent is distilled from the percolate at ordinary pressure, leaving a watery residue mixed with a quantity of resin and fat. This is repeatedly extracted with boiling water to remove all water-soluble constituents. The water layers are siphoned off after each extraction. The final resinous residue is then extracted with boiling 50 per cent alcohol as long as soluble matter is obtained. 
The alcoholic solutions are filtered off hot, united, and distilled to remore alcohol. The watery residue is allowed to cool and is filtered from precipitated resins. These resins are then extracted with boiling 30 per cent alcohol as long as they vield soluble matter. The solutions are filtered hot and the alcohol is remored from them. Crude tremetol ester separates out. This is purified by solution in alcohol and by boiling with 5 per cent alcoholic potash to hydrolyze the ester.

When hydrolysis is complete the alcohol is evaporated from the reaction product, and the residue is dissolved in water and extracted with ether, which dissolves the tremetol together with some coloring matters. The ether solution is poured into four volumes of petroleum ether, as a result of which process most of the coloring matters and other impurities are precipitated. Tremetol is recorered by evaporating the solvent, and should be purified by repeated solution in ether and precipitation with petroleum ether. The purity of the product may be determined by optical rotation and by ascertaining molecular weight. The absence of ash and deep color also indicates purity.

\section{A Color Reaction of Tremetol}

When a small quantity of tremetol is dissolved in petroleum ether and the solution is floated on the surface of concentrated sulphuric acid contained in a test tube, a red ring forms at the interface. If the two liquids are mixed by gentle agitation the petroleum ether is colored a transient cherry red which rapidly fades and the acid laver acquires a brilliant cherry-red color. If the solution is too dilute a yellow or orange may be the only result; if it is too concentrated or if much impurity is present the color reaction may be obscured by carbonization.

This reaction is offered as a provisional test for the presence of tremetol in Eupatorium mixtures. While there are numerous other substances which yield red colors with concentrated sulphuric acid, many of them are insoluble in petroleum ether and would not interfere with the test. Others give different shades of red. The cherry red giren by tremetol is quite characteristic. A negative test definitely establishes the absence of tremetol; a positive reaction taken in conjunction with other data may demonstrate the presence of that substance.

A careful study of the applicability and specific nature of this test is in progress. It is hoped that through this color reaction a method may be developed by which suspected milk may be tested and dangerous milk detected, in areas where milk sickness exists.

It has been possible to use this test in order to check up on feeding experiments, particularly when failure to produce poisoning by extracts was not explicable. Unfortunately, samples of some of the extracts used during the course of this study were not available when the test was discovered and could not be tested. The results are stated in connection with the rarious discussions of the extracts.

\section{COLLECTION OF PLANT MATERIAL}

The plant material used in this investigation was collected in two localities in Illinois and in one place in Virginia, as shown in Table 1. The Illinois plant was gathered partly in the neighborhood of Beecher 
City and partly at Paxton, in both of which localities milk sickness had appeared. The Virginia plant was collected on the banks of the Potomac River, Arlington County, in the neighborhood of Washington, D. C., a district from which no record of milk sickness has come. Both green and dried plants were studied. The dried plant originated wholly in Beecher City, Ill. One lot of green plant was collected at Beecher City, and was packed in milk cans, covered with chloroform water to preserve it, and shipped to Washington, D. C. Other lots of green material from Illinois were mailed to Washington where they arrived in fresh condition and were immediately hashed and put into strong alcohol. Green material was collected in Virginia and was carried to the laboratory within 24 hours. When used for direct feeding, the plant was usually collected early in the morning and was carried immediately to the laboratory. One lot of green plant, collected in Virginia by W. N. Berg, was immediately placed by him in strong alcohol and had been macerated for two years when it was worked up during the present study. ${ }^{3}$

TABLE 1.-Collections of Eupatorium urticaefolium

\begin{tabular}{|c|c|c|c|c|c|}
\hline Lot No. & Date collected & $\begin{array}{l}\text { Condition } \\
\text { when used }\end{array}$ & Place of collection & Weight & Collector \\
\hline E 1 & Nor. 17,1916 & Green & Arlington $\mathrm{Co} ., \mathrm{Va}_{2}$ & Kgm. & IV. N. Berg. \\
\hline E 2 - & October, 1915 & Dry & $\begin{array}{l}\text { Fancher (Beceher City), } \\
\text { 1ll. }\end{array}$ & 4.432 & A. B. Clawson. \\
\hline E 3. & Oct. $7-22,1921$ & Green..... & Woodmont, Va_......... & 13. 63 & J. F. Couch. \\
\hline E 4 & Apr. $20-30,1925$ & _. do & 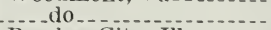 & 7.27 & Do. \\
\hline E 5 & Sept. 22,1920 & do & Beccher City, Ill & 28.0 & Do. \\
\hline E 6 & Sept. 25 -Oct. 3,192 & ... do . & Woodmont, Va......... & 53.32 & Do. \\
\hline E 7. & October, 1922 & $\ldots \mathrm{do}$ & $\begin{array}{l}\text { Beecher City and Pax- } \\
\text { ton, 1ll. }\end{array}$ & 35.9 & $\begin{array}{l}\text { J. M. Casstevens and } \\
\text { J. E. Parks. }\end{array}$ \\
\hline E 8 . & October, 1915 & Dry.-. & Beecher City, Ill.... & 18. 93 & A. B. Clawson. \\
\hline E 9 & October, 1923.. & Green. & $\begin{array}{l}\text { Bepcher City and Pax- } \\
\text { ton, } 11 \text {. }\end{array}$ & 98.5 & $\begin{array}{l}\text { J. M. Casstevens and } \\
\text { J. E. Parks. }\end{array}$ \\
\hline E 10 & September, 1925. & _. do & Beecher City, Ill ........ & 131.8 & J. M. Casstevens. \\
\hline
\end{tabular}

ANIMALS USED IN THE EXPERIMENTAL WORK

The earlier experiments to test the toxicity of various extracts and their fractions were made on guinea pigs, but the variability of the results obtained with these animals and the impossibility of their exhibiting the symptoms characteristic of trembles in cattle led to abandonment of guinea pigs in faror of sheep. It was on the latter animal that all the crucial experiments were made. Cats were used in certain feeding tests, and rabbits were used in testing the toxicity of the resin acid.

All animals were allowed access to plenty of feed and water during the experiments. These experiments are summarized in Table 2.

3 The writer desires to express his thanks to those who assisted in the collection of plant material, and especially to J. M. Casstevens and to J. E. Parks, of lllinois, Specimens of the various collections were submitted to S. F. Blake, botanist at the Bureau of Plant Industry, for identification before they were used in this investigation.

$$
61876-27-2
$$




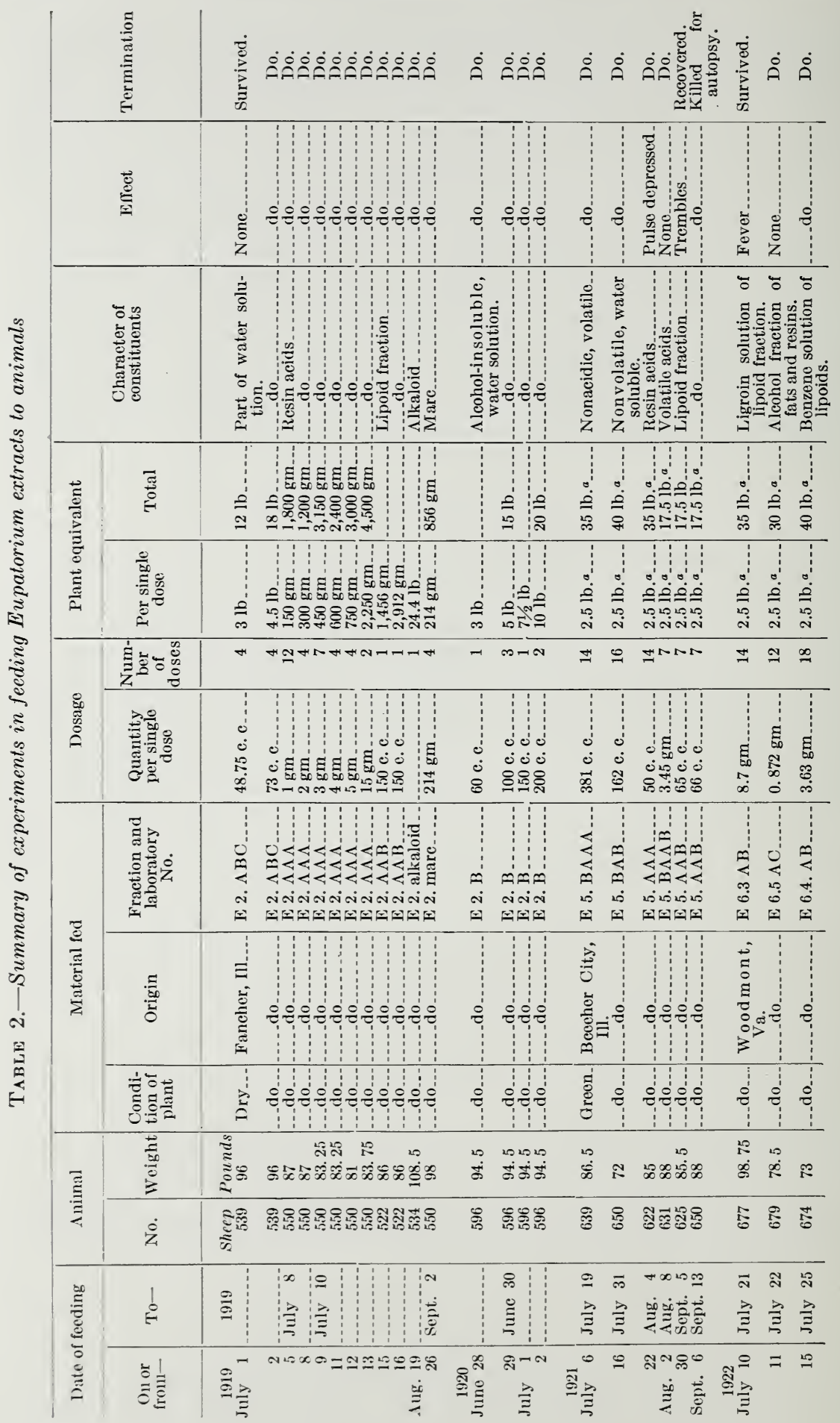


ค่

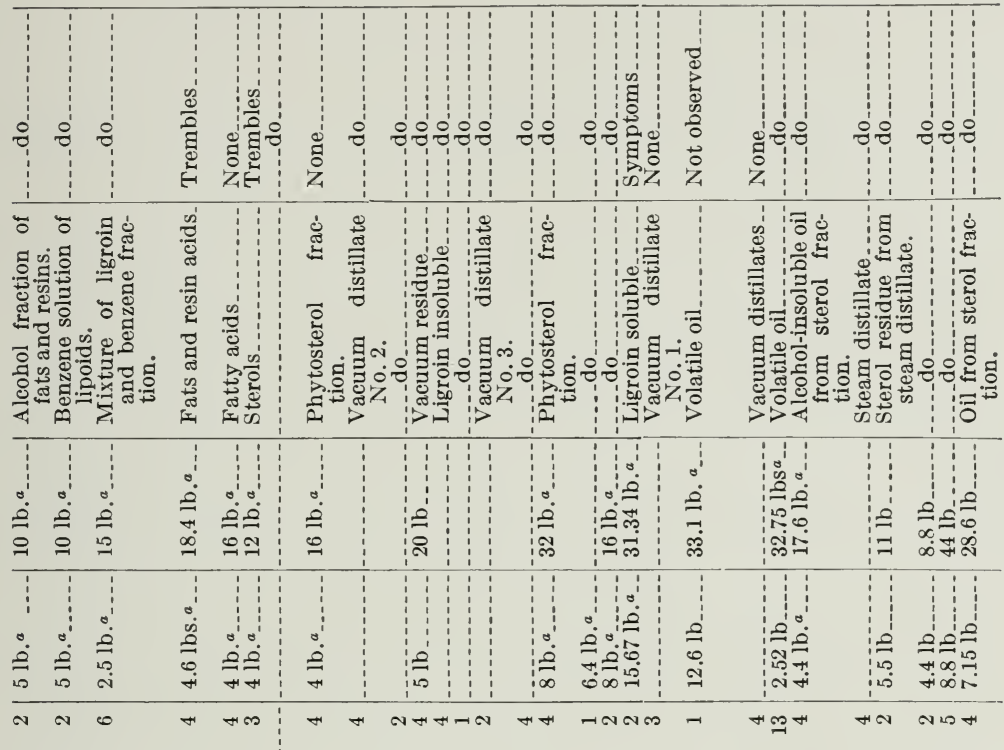

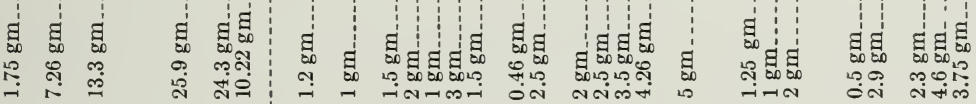

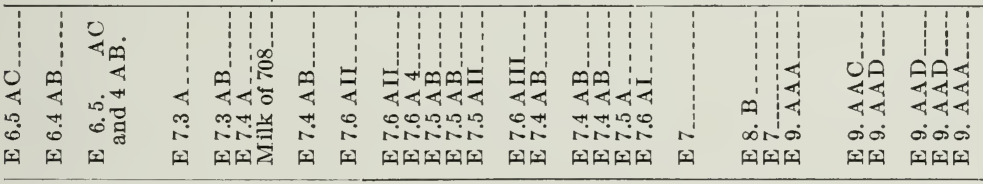

\%

o

央

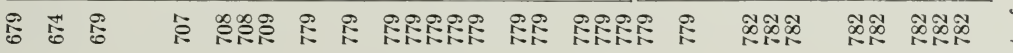

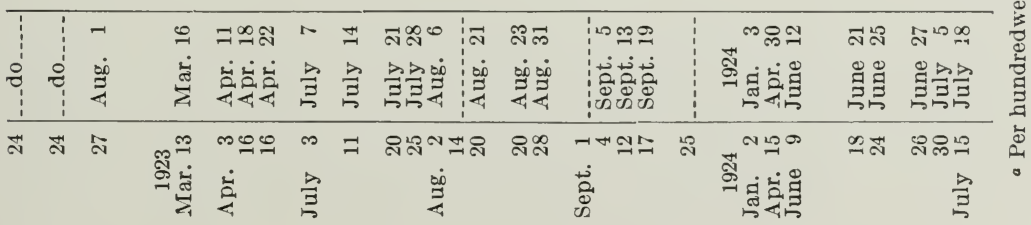




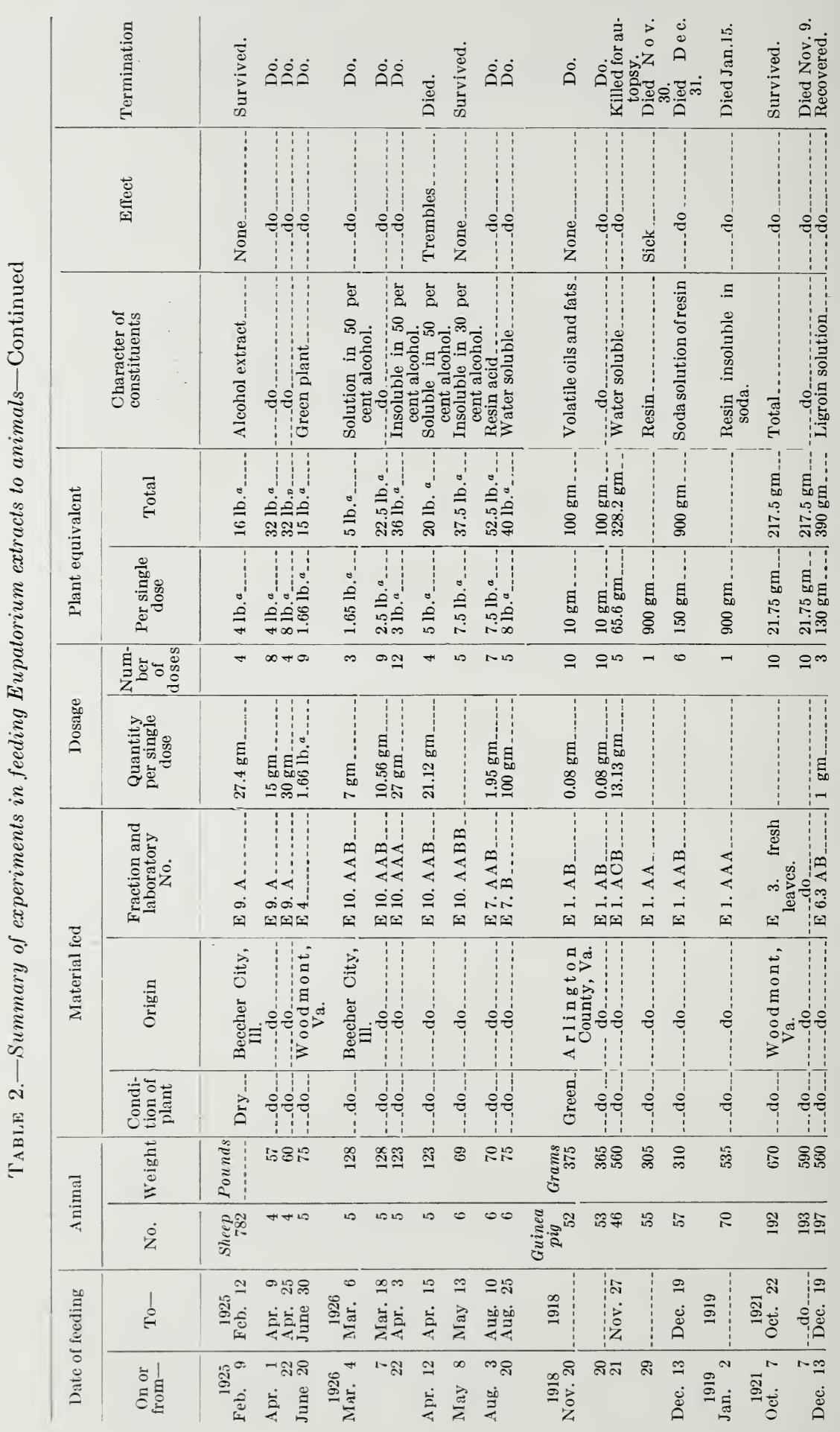




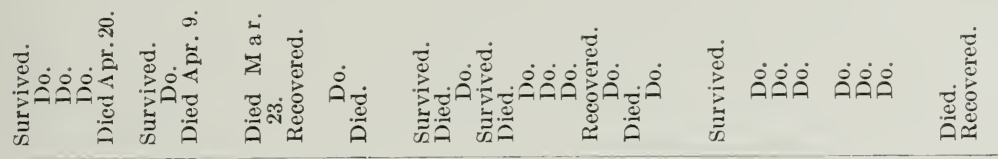

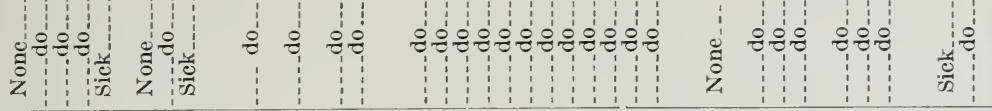

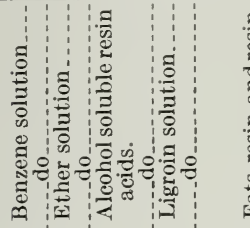

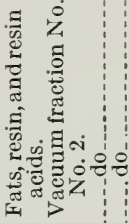

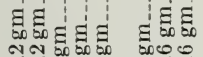

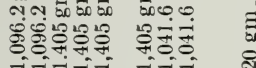

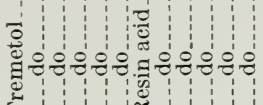

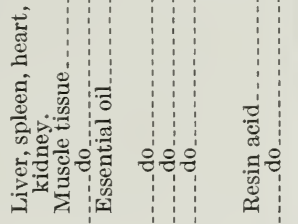

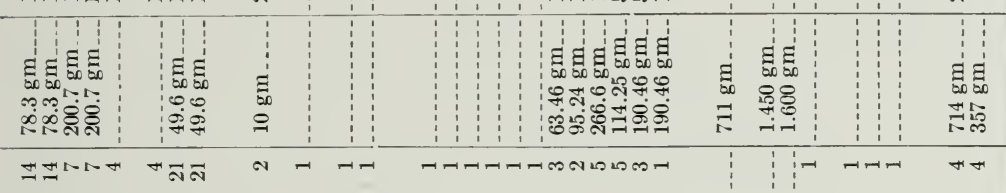

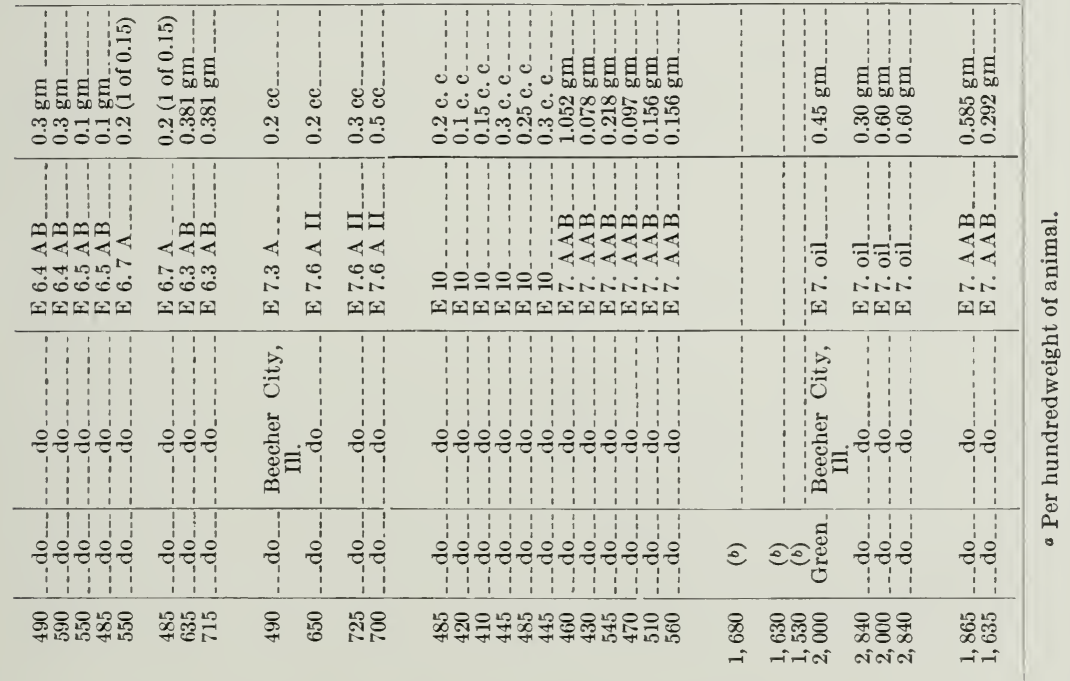

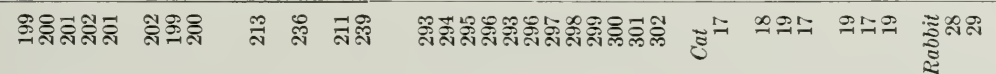

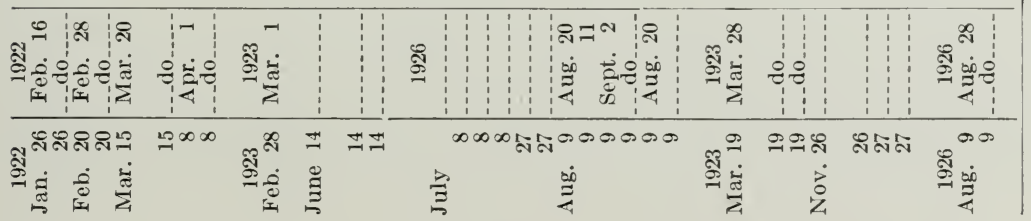


Eight of the lots of plant collected for use in this study were submitted to extraction and fractionation processes, and inasmuch as the procedure was similar in every case a composite description of the procedure followed is presented here, the rarious fractions being distinguished by a lot number in order to insure clearness. The fractions are further grouped according to the chemical character of the substances present so that comparison may be made between various fractions and between plants from different collections.

In general, the fresh plants were subjected to the following process to extract the soluble constituents and to fractionate the extracts so obtained: The fresh plant was hashed and placed in strong alcohol in a percolator. After two days' maceration the plant was extracted with alcohol br intermittent percolation; the alcohol was remored from the percolate br distillation at atmospheric pressure and was returned to the percolator. The residue from the distillation was mixed with water and redistilled to remore the last traces of alcohol and also to drive off the rolatile oil which was recorered.

The residue so obtained consisted of a greenish, insoluble mass of lardy consistency, and a watery solution. The water solution was siphoned off, and the insoluble residue was repeatedly extracted with boiling water as long as it yielded soluble matter. The combined water extracts furnished one fraction.

The insoluble matter was next treated with hot 1 per cent sodiumcarbonate solution which dissolved out a resin acid fraction, learing undissolved what was termed the "lipoid" fraction. The latter was fractionated in various ways, which are described in connection with the testing of the fractions themselres.

The water-soluble materials were fed in aqueous solution. The resin acid was fed in sodium-carbonate solution, and other materials were emulsified in water or in sirup by means of acacia.

\section{FRESH LEAVES}

Leares from plants collected at Woodmont, Va., were fed to two guinea pigs October 7 to 22,1921 , a total of 10 doses, areraging $21.75 \mathrm{gm}$. per dose, being giren. The animals had access to oats during the experiment. Both were made sick, and one died 15 davs after the last feeding. Post-mortem examination showed liver and kidneys pale, lungs congested, and congestion in the stomach and colon. The other animal survired.

Sheep 5 was fed by balling gun nine doses of fresh leares collected at Woodmont, Va. From June 20 to 30,1925 , this sheep was fed $5,123 \mathrm{gm}$. of fresh plant, equiralent to 15 pounds per hundredweight of animal. This feeding produced no effect on the animal.

\section{TOTAL WATER-SOLUBLE NONVOLATILE CONSTITUENTS}

The material of plant lot E 5, collected in Beecher City, Ill., and shipped to Washington preserved in chloroform water, was allowed to stand in storage during the winter. It was opened in May, 1921, when the water solution was strained off. The leares of the plant were stripped from the stems, hashed in a meat chopper and pressed out, the strained juice being added to the water solution. Half of 
the solution was distilled from a copper still until volatile substance, other than water ceased to appear in the distillate. The nonvolatile residue $(\mathrm{E} 5 . \mathrm{BAB})$ was collected and used for a feeding test. This was a limpid, faintly greenish-brown, acid liquid, of bitter, saline, and highly unpleasant taste. It was colored deep green with ferric chloride, even after the removal of possible tannins with gelatine solution. It yielded no alkaloid test with Mayer's solution. Alcohol precipitated a large amount of gray, flocculent matter (inulin). The whole residue was concentrated to $2,700 \mathrm{c}$. c. by evaporation.

Sixteen doses of 162 c. c. of this solution, corresponding to 2.5 pounds of fresh plant per hundredweight of animal, were drenched in to sheep 650 from July 16 to July 31, 1921. The total dosage was 2,592 c. c., equivalent to 40 pounds of plant per hundredweight. The sheep was not affected by this treatment.

VOLATILE OIL

Volatile oils were obtained in concentrating alcoholic extracts of Eupatorium. Oils obtained from green plant gave a positive test for tremetol; a sample from dry plant was negative. An emulsion containing $5 \mathrm{gm}$. of oil obtained from lot $\mathrm{E} 7$ was drenched into sheep 779 September 25,1923 , at 1 p. m. The animal was observed during the afternoon but showed nothing abnormal. It was found dead, however, on the following day at $6.30 \mathrm{a} . \mathrm{m}$.

A post-mortem examination conducted during the morning by G. T. Creech, of the pathological division, revealed hemorrhagic areas on the endocardium; the liver pale and degenerate; the kidneys degenerate; hemorrhages in the lower end of ileum and duodenum; and thyroid and thymus congested. There was much fluid in the abdominal cavity. Certain of these abdominal conditions were considered to be of longer standing than the present feeding would account for, and possibly were the result of earlier experiments made on this sheep.

The volatile oil, emulsified in sirup with acacia, was fed to cats 17 and 19. On November 26,1923 , cat 17 received $0.45 \mathrm{gm}$. of oil and November 27, $0.60 \mathrm{gm}$. On November 26 cat 19 received $0.30 \mathrm{gm}$. and November 27, $0.60 \mathrm{gm}$. of oil. Both animals survived the doses and showed no abnormal effects from them.

From April 15 to 30,1924 , sheep 782 was given 13 daily doses of $1 \mathrm{gm}$. each of oil, emulsified in sirup with acacia. The total dosage, equivalent to 32.75 pounds of green plant per hundredweight of animal, produced no effect.

From these experiments it is apparent that the essential oil, while toxic in large doses, is not the constituent responsible for trembles.

\section{WATER- AND ALCOHOL-SOLUBLE CONSTITUENTS}

LOT NO. E 1

The material consisted of $1,805 \mathrm{gm}$. of green plant that had been hashed and put into alcohol November 17, 1916, by W. N. Berg, then of this laboratory, who turned the specimen over to the writer in 1918. October 15, 1918, it was packed into two glass percolators and exhausted with strong alcohol. The alcohol was removed from the percolate by distillation, leaving a brown, aqueous solution on 
the surface of which was an oily layer. A resinous precipitate was distributed throughout the aqueous solution. The whole was extracted with petroleum ether (E 1. AB). The water residue was filtered from the precipitated resin and tested on guinea pig 46, in $10 \mathrm{c}$. c. doses, equivalent to $65.64 \mathrm{gm}$. of green plant. Five doses were given from November 21 to November 27. The animal showed no abnormal effects from these doses. It was killed for autopsy, which revealed a slight gastroenteritis.

\section{LOT NO. E 2}

Four thousand four hundred and thirty-two gm.of dried whole plant were ground to a No. 20 powder and extracted with strong alcohol. The solvent was distilled from the percolate and the resinous residue extracted with boiling water. The filtered water solution was evaporated to convenient bulk. It responded to Mayer's test for alkaloids; consequently it was made alkaline with sodium hydroxide and shaken out first with chloroform which removed very little, and then with amyl alcohol which removed a basic substance.

\section{VOLATILE, WATER-SOLUBLE MATERIAL}

The distillate from the water solution of $\mathrm{E} 5$ was cohobated until its volume was reduced to 6 liters. It was treated with a slight excess of sodium hydroxide and submitted to steam distillation until pure water alone came over. The distillate (E 5. BAAA) bore the characteristic odor of the plant, but only minute quantities of oil separated. It did not react with ferric chloride. Fourteen doses of it drenched into sheep 639 resulted in no other effect than a slight catharsis. The alkaline residue (E 5 . BAAB) was evaporated to dryness when it weighed $48 \mathrm{gm}$. Half of it was dissolved in water, neutralized with acetic acid, and fed to sheep 631 in divided doses. The sheep remained normal.

The extracted water solution (E 2. ABC) was fed to sheep 539. Four doses estimated to represent 3 pounds of green plant each and 4 doses estimated to represent 4.5 pounds of green plant each, a total of 30 pounds, fed to this animal, produced no ill effects.

The press cake (see p. 560) was extracted similarly with alcohol. The resinous residue obtained was fractionated with sodium-carbonate solution which dissolved the remaining water-soluble constituents as well as a resin acid. The testing of this fraction is described under the heading "Resin acids."

LOTS NOS. E 6, E 7, E 9, AND E 10

E 6, E 7, E 9, and E 10 yielded similar water solutions. E 6 B was fed to sheep 6 in 100 gm. doses. Five daily doses each, equivalent to 8 pounds per hundredweight given to the animals, produced no effect. The water solution gave evidence of the presence of a glucoside and responded to Mayer's test. Acetic acid was present, and levulose, probably resulting from the hydrolysis of inulin, was detected. The water solution from $\mathrm{E} 7$ was tested for tremetol with negative results. 


\section{ALKALOID}

The amyl-alcohol solution containing the alkaloidal substance extracted from E 2 . ABC was treated with dilute hydrochloric acid which extracted the base. A quantity of this, estimated to be equivalent to 24.4 pounds of green plant, was fed to sheep 534 August 19,1919 , and did not affect the animal.

\section{ALCOHOL-SOLUBLE, WATER-INSOLUBLE CONSTITUENTS}

Fats, Resins, Resin Acids, Esters

LOT NO. E 1

Half of the resinous precipitate was emulsified in mucilage or Irish moss and given to guinea pig 55 in a dose equivalent to $900 \mathrm{gm}$. of the green plant. The animal died during the night after showing symptoms of depression. The autopsy was negative.

Thereafter all resinous fractions were treated with sodium-carbonate solution before testing on experimental animals.

The remaining half of the resinous fraction was treated with sodium carbonate solution which dissolved a large portion of it. This fraction was given to guinea pig 57 in doses beginning December 13, 1918. The animal became depressed, rapidly lost weight and died on December 31 showing symptoms of respiratory paralysis. An autopsy showed the animal greatly emaciated; the organs, however, appeared normal.

LOT NO. E 2

A similar fraction containing resin acids (E 2. AAA) was dissolved in sodium-carbonate solution and fed to sheep 550 in 33 doses from July 5 to July 13, 1919. The quantity fed was increased from 1 to $15 \mathrm{gm}$. per dose. An equivalent of 35.31 pounds of green plant fed to the sheep during this period produced no effect.

LOT No. E 5

The resin-acid fraction from this extraction (E 5. AAA) was dissolved in sodium-carbonate solution and fed to sheep 622 from July 22 to August 4, 1921, in doses equivalent to 2.5 pounds per hundredweight. Fourteen doses were administered, equal to 35 pounds of green plant. There was a slight but definite depression of the pulse but no other abnormal symptom was observed and the animal recovered.

LOT NO. E 7

The homologous fraction (E 7. AAB) was fed to sheep 6 from August 3 to August 10, 1926, in seven daily doses, each equivalent to 7.5 pounds of green plant per hundredweight of animal, or a total of 52.5 pounds. There was no effect from this feeding.

A series of feedings of this fraction were made to 6 guinea pigs and 2 rabbits. The results are tabulated in Tables 3 and 4 . Of the 6 guinea pigs, 5 were made sick and 4 of them died. 
TABLE 3.-Quantities of resin acids fed to rabbits and guinea pigs, 1926

\begin{tabular}{|c|c|c|c|c|c|c|c|c|}
\hline \multirow{2}{*}{ Date } & \multicolumn{6}{|c|}{ Guinea pig No. } & \multicolumn{2}{|c|}{ Rabbit No. } \\
\hline & 297 & 298 & 299 & 300 & 301 & 302 & 28 & 29 \\
\hline $\begin{array}{l}\text { Aug. } 9 \\
\text { Aug. } 11 \\
\text { Aug. } 20 \\
\text { Aug. } 28 \\
\text { Sept. } 2\end{array}$ & 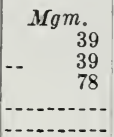 & $\begin{array}{r}M_{78} \\
78 \\
\end{array}$ & $\begin{array}{c}\text { Mgm. } \\
136.5 \\
136.5 \\
273 \\
273 \\
273\end{array}$ & $\begin{array}{c}M g m . \\
58.5 \\
58.5 \\
117 \\
117 \\
117\end{array}$ & $\begin{array}{r}M g m . \\
117 \\
117 \\
234\end{array}$ & \begin{tabular}{c}
$M_{156}$ \\
\hdashline \\
\hdashline
\end{tabular} & $\begin{array}{l}\text { Mgm. } \\
476.15 \\
476.15 \\
952.3 \\
952.3\end{array}$ & $\begin{array}{r}\text { Mgm. } \\
238.07 \\
238.07 \\
476.15 \\
476.15\end{array}$ \\
\hline
\end{tabular}

TABLE 4.-Weights of guinea pigs and rabbits fed resin acids, 1926-27

\begin{tabular}{|c|c|c|c|c|c|c|c|c|}
\hline \multirow{2}{*}{ Date } & \multicolumn{6}{|c|}{ Guinea pig No. } & \multicolumn{2}{|c|}{ Rabbit No. } \\
\hline & 297 & 298 & 299 & 300 & 301 & 302 & 28 & 29 \\
\hline 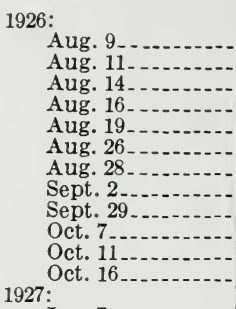 & $\begin{array}{c}\text { Grams } \\
460 \\
480 \\
470 \\
435 \\
400 \\
330 \\
310 \\
\text { Dead. }\end{array}$ & $\begin{array}{r}\text { Grams } \\
430 \\
450 \\
400 \\
355 \\
\text { Dead. } \\
\end{array}$ & $\begin{array}{r}\text { Grams } \\
545 \\
550 \\
580 \\
575 \\
595 \\
625 \\
625 \\
640\end{array}$ & $\begin{array}{rr}\text { Grams } \\
470 \\
490 \\
495 \\
495 \\
525 \\
545 \\
540 \\
525\end{array}$ & $\begin{array}{r}\text { Grams } \\
510 \\
510 \\
500 \\
500 \\
520 \\
\text { Dead. } \\
\end{array}$ & $\begin{array}{r}\begin{array}{r}\text { Grams } \\
560 \\
\text { Dead. }\end{array} \\
\\
\end{array}$ & $\begin{array}{r}\text { Grams } \\
1,865 \\
1,845 \\
1,815 \\
1,880 \\
1,870 \\
1,895 \\
1,895 \\
1,880 \\
1,550 \\
1,380 \\
1,305 \\
1,115\end{array}$ & $\begin{array}{c}\text { Grams } \\
1,635 \\
1,595 \\
1,595 \\
1,605 \\
1,610 \\
1,630 \\
1,605 \\
1,670 \\
1,790 \\
1,740 \\
1,715 \\
1,690\end{array}$ \\
\hline 1927: Jan. 7 & & & & & & & & 1,450 \\
\hline
\end{tabular}

Guinea pig 302 may have succumbed to a traumatic pneumonia. The three other pigs remaining, which died from the dosage, all showed the same symptoms of depression. The autopsies revealed anemia, great emaciation, enlarged liver and spleen. The urine collected at autopsy was usually pale, cloudy, acid, and contained albumin. Acetone, dicetic acid, and reducing substances were not found. The two rabbits fed were made sick. Rabbit 28 died October 17, after losing a total of $750 \mathrm{gm}$. of its original weight. The post-mortem examination revealed emaciation and anemia. Urine collected at autopsy was acid and contained albumin. Sugar and acetone bodies were absent.

Rabbit 29 was observed for five months and was finally discharged January 7,1927 , when he had lost a total of $185 \mathrm{gm}$. of his original weight. This animal survived the treatment, but appeared to be permanently affected, inasmuch as he failed to gain weight or to recover from depression, although more than four months had elasped since the last feeding of resin acids.

\title{
NONACIDIC CONSTITUENTS OF THE RESINOUS FRACTION
}

Fats, Waxes, Esters, and "Lipoid Fraction"

\author{
LOT NO. E 1
}

The portion of the resin not soluble in sodium carbonate was emulsified in 50 per cent alcohol and given to guinea pig 70 January 2 , 1919. The animal became depressed, lost 26 per cent of his 
original weight, and finally died January 14. Post-mortem change was so far advanced that no conclusions could be drawn from the autopsy.

LOT NO. E 2

A similar fraction (E 2. AAB) was emulsified in water and drenched into sheep 522 in two doses. No effect was observed.

LOT NO. E 5

The corresponding fraction (E $5 . \mathrm{AAB}$ ) was emulsified in water with acacia and seven doses of $65 \mathrm{c}$. c. each, equivalent to 2.5 pounds of green plant per hundredweight of animal, were given to sheep 625 from August 30 to September 5, 1921 . The sheep developed a positive case of trembles. Feeding was discontinued and the animal slowly recovered. Another portion of the same fraction was given in seven doses of $66 \mathrm{c}$. c. (2.5 pounds per hundredweight) to sheep 650 from September 6 to September 13. The animal developed a positive case of trembles. She was killed for autopsy September 19. The post-mortem examination showed some slight congestion in the lower ileum, liver pale and yellowish, and the cortex of the kidney dark. A sample of blood drawn from the left jugular vein immediately after death was tested for acetone bodies, with a positive result.

Specimens of urine obtained from both sheep 625 and sheep 650 contained acetone, and the odor of that ketone was noticeable on the exhaled air in both cases.

LOT NO. E 6

The corresponding fraction from this extraction (E 6. AAA) was not fed as such but was divided by means of solvents into several portions, as follows:

Petroleum ether extracted _._ 0.768 per cent of green plant (E 6. 3AB)

Benzene extracted..... 0.36 per cent of green plant (E 6. 4AB)

Alcohol extracted....... 0.098 per cent of green plant $(\mathrm{E} 6.5 \mathrm{AC})$

The alcohol extract was divided, and a small portion of it was extracted successively with ether and chloroform, as follows:

Ether extracted _... 0.062 per cent of green plant (E 6. 5AB)

Chloroform extracted.... 0.033 per cent of green plant (E 6. 6AB)

The material extracted by the solvents was given to sheep and guinea pigs.

The petroleum-ether fraction was emulsified in water with acacia and 12 doses, each equivalent to 2.5 pounds of green plant per hundredweight of animal, were drenched into sheep 677 from July 10 to July 21, 1922, with no effect on the animal. Three doses of $1 \mathrm{gm}$. each (emulsified) were given to guinea pig 197 from December 13 to December 19, 1921. The animal was made sick but recovered.

A series of 21 doses of the fraction emulsified in water with acacia were given to guinea pigs 199 and 200 from March 8 to April 1, 1922, the doses being gradually increased from 2 to $5 \mathrm{gm}$. during the interval. Guinea pig 200 was made sick and died April 9. Pig 199 showed no abnormal effect from the feeding and survived. Guinea pig 197 which received $3 \mathrm{gm}$. doses of this fraction from December 13 to December 19, 1921, was made sick, but eventually recovered. This fraction gave a faintly positive test for tremetol. 
The benzene fraction was emulsified in water with acacia and fed to guinea pigs 199 and 200 from January 26 to February 16, 1922. Each animal received 14 doses of $0.3 \mathrm{gm}$. corresponding to $78.3 \mathrm{gm}$. of green plant, or a total of $1,096.2 \mathrm{gm}$. of green plant for the entire period. Neither animal was affected by this treatment; both gained weight and appeared perfectly healthy during the experiment. The fraction was emulsified and fed to sheep 674 from July 15 to July 25, 1922 , in eight doses of 2.5 pounds and two doses of 5 pounds of green plant per hundredweight. The total dosage, 30 pounds, did not affect the animal. This fraction did not respond to the test for tremetol.

The ether fraction was emulsified in water with acacia and fed to guinea pigs 201 and 202. Each animal received seven daily doses of $0.1 \mathrm{gm}$., equivalent in all to $200.7 \mathrm{gm}$. of green plant, from February 20 to February 28, 1922. Neither animal was affected by the material given.

The alcohol fraction was emulsified in water with acacia and fed to sheep 679 in 12 daily doses of 2.5 pounds per hundredweight from July 11 to July 22, 1922 . On July 24 and 25 the doses were doubled so that the sheep received a total of 40 pounds per hundredweight. The sheep showed some slight symptoms of colic on July 22 and 23 but otherwise remained normal. The alcohol fraction was also fed to guinea pigs 201 and 202 in four doses totaling $0.75 \mathrm{gm}$. of fraction, equivalent to $1,405 \mathrm{gm}$. of green plant. No. 202 was not affected, but No. 201 became sick and died one month after the last feeding. The post-mortem examination revealed anemia, a pale liver, and pale kidneys. The fraction did not respond to the test for tremetol.

A mixture of the petroleum-ether and benzene fractions was made in equivalent proportions, and this mixture, equal to 15 pounds of green plant per hundredweight of sheep, was emulsified in water with acacia and fed to sheep 679 from July 27 to August 1, 1922, in immediate succession to feedings with the alcohol extract. (See above.) There was no effect from this treatment.

LOT NO. E 7

The residue obtained by distilling the solvent from the alcoholic percolate of this plant consisted of mixed fats, resins, and water solution. It was so difficult to filter that it was extracted with benzene, which dissolved the major portion of the water-insoluble matter present. The benzene solution was washed with several portions of aqueous sodium carbonate to free it from acidic constituents, separated from the water solution, and the benzene distilled off. The residue was a deep-green mass of the consistency of lard. It weighed $664 \mathrm{gm}$. and constituted 2.04 per cent of the green plant extracted. Four daily doses of an emulsion of this fraction were given in drenches to sheep 707. The animal received a total of 18.4 pounds of green plant equivalent per hundredweight from March 13 to March 16, 1923. The animal developed trembles and died during the night of March 18. The post-mortem examination revealed the lungs congested, light-colored areas in the liver which had the appearance of fatty degeneration, and the spleen pale. The other organs and the musculature were pale. Post-mortem change was marked. The 
meat from this carcass was fed to cats 17, 18, and 19 from March 19 to March 28, 1923, but did not affect them.

Two doses of this fraction were given to guinea pig 213 , the first February 28 and the second March 1, 1923. Each dose consisted of $0.2 \mathrm{gm}$. of the fraction and was equivalent to $10 \mathrm{gm}$. of green plant. The animal remained normal until March 10, when symptoms of depression appeared. These became progressively worse and the animal died March 23. The autopsy showed some congestion of the lungs, spleen pale and brownish, liver dark, and other organs normal. Urine taken from the bladder did not contain acetone.

LOT NO. E 9

A similar fraction (E 9. A) was emulsified in sirup with acacia and four doses of $27.4 \mathrm{gm}$., equivalent in all to 16 pounds of green plant per hundredweight, were given to sheep 782 from February 9 to February 12,1925 , without affecting the animal. The same fraction was fed twice to sheep 4 without producing trembles; from April 1 to April 9, 1925, this sheep received eight daily doses of $15 \mathrm{gm} .$, a total of 32 pounds of green plant per hundredweight, and from April 22 to April 25, 1925, the sheep received four daily doses of $30 \mathrm{gm}$., equivalent in all to 32 pounds of green plant per hundredweight. Various fractions of this extract were also fed and are described below. In no case were symptoms observed and it was concluded that the original plant was nontoxic or that the process of extracting the soluble constituents had in some way altered the toxic principle.

Inasmuch as E 7 was processed in the same way and was toxic, it does not seem probable that the last hypothesis is correct. This fraction was later tested for tremetol and was found to contain a very small quantity of the toxic substance.

LOT NO. E 10

The corresponding fraction from this lot was obtained by treating the residue that remained, after the alcohol had been distilled from the percolate, with boiling water as long as soluble material was extracted. The insoluble material was then extracted with boiling 50 per cent alcohol as long as anything could be extracted. The insoluble matter was labeled E 10. AAA. It gave no test for tremetol. Twelve daily doses of this fraction, emulsified in sirup with acacia, and consisting of $27 \mathrm{gm}$. each, equivalent to 3 pounds of green plant. per hundredweight, were given to sheep 5 from March 22 to April 3, 1926. The sheep was not affected. The material dissolved in 50 per cent alcohol was recovered by distilling off the solvent. This fraction responded to the test for tremetol. It was emulsified in sirup with acacia and given to sheep 5. From March 4 to March 6, 1926, the sheep received three daily doses of $7 \mathrm{gm}$., equivalent to 1.65 pourids of green plant per hundredweight. From March 7 to March 18, 1926, the sheep received nine daily doses of $10.56 \mathrm{gm}$., equivalent to 2.5 pounds per hundredweight. No effect was apparent, although the total dosage was equivalent to 27.5 pounds of green plant.

From April 12 to April 15, 1926, the same sheep was given four daily doses of $21.12 \mathrm{gm}$. each, corresponding to 5 pounds of green plant per hundredweight, or a total of 20 pounds. The sheep remained normal until April 16, when he began to tremble. He became pro- 
gressively worse and died April 22. During the sickness several samples of urine and blood were obtained. On April 16, when trembling first appeared, the sheep was not excreting acetone bodies, but on the following morning there was an acetone odor on the breath and the urine contained a quantity of this ketone. From that day onward the animal excreted acetone continuously by the lungs and kidneys. At autopsy the only marked abnormality was apparent degeneration of the liver. The carcass had a strong odor of acetone. Blood and urine, collected at autopsy, were tested and found to contain acetone. In the urine the proportion of acetone was $24.32 \mathrm{mg}$. per $100 \mathrm{c}$. c. The blood sugar was markedly high during the sickness. On March 22 , when the sheep appeared to be normal, a sample of blood drawn from the left jugular vein was subjected to analysis and the content of blood sugar was determined as $0.104 \mathrm{gm}$. per 100 c. c. Blood drawn similarly April 16 when the sheep was trembling gave an average of $0.168 \mathrm{gm}$. per $100 \mathrm{c}$. c. for two determinations. At this time feeding with the Eupatorium extract was discontinued and the sheep was given oats. Another sample of blood was taken April 22 from which a blood sugar content of $0.138 \mathrm{gm}$. per $100 \mathrm{c}$. c. was determined.

The remainder of the extract that had proved fatal to sheep 5 was treated with boiling 30 per cent alcohol in successive portions as long as soluble matter was dissolved. The insoluble residue (E 10. AABB) which gave no test for tremetol, was tested on sheep 6 . Five daily doses of the emulsified material, equivalent to 7.5 pounds of green plant per hundredweight of sheep per dose, were given from May 8 to May 13, 1926. The total dosage was 37.5 pounds. There was no effect from this feeding.

The results obtained from feeding experiments with the "lipoid" fraction indicated clearly that the toxic principle responsible for trembles was contained in that fraction. Failure to produce poisoning in sheep with the extracts made from lots $\mathrm{E} 6$ and $\mathrm{E} 9$ was apparently due to their small content of tremetol. Lot $\mathrm{E} 6$ was collected at Woodmont, Va., in a district where milk sickness had not been observed, so far as the writer knows. It is possible that plants from this locality are innocuous. Lot E 9, however, was collected in two places in Illinois from which very toxic plants were obtained at other times. Lot $\mathrm{E} 2$ failed to yield a toxic lipoid fraction; this material was dried plant, however, and was not expected to be very toxic.

HYDROLYSIS OF THE LIPOID FRACTION

LOT NO. E 7

Failure to obtain crystalline substances by chemical treatment of the fraction led to the decision to hydrolyze it with alcoholic potassium hydroxide. Accordingly this was done. A quantity of the toxic fraction was boiled under reflux with 5 per cent alcoholic potash until hydrolysis was complete; the alcohol was then removed and the bright-green residue was treated with water in which the soaps dissolved and emulsified the insoluble matter. This mixture was then repeatedly extracted with ether, which slowly removed a yellowish mass that was obtained by evaporating the solvent. The residue is described below as the "sterol" fraction. The soaps were decomposed with hydrochloric acid, and the precipitated mass was filtered off. The tests made on this material are described under the heading 
"fatty acids." The filtrate was further extracted with ether to recover the water-soluble acids; the ether was shaken with sodiumcarbonate solution, which took out a small quantity of acetic acid. Following the ether extraction the water solution was evaporated to small volume, and glycerine was detected in the residue.

THE FATTY ACIDS

LOT NO. E 7

The precipitate containing the fatty acids was washed with water, and a portion was emulsified in acacia and water for feeding. From April 3 to April 11, 1923, sheep 708 received four doses of this emulsion, each equivalent to 4 pounds of green plant per hundredweight, or a total of $24.3 \mathrm{gm}$. of the fraction.

On April 4 the sheep gave birth to a normal lamb. The animal was rested for 5 days before the experiment was resumed. There was no toxic effect from this feeding.

\section{THE STEROL FRACTION}

LOT NO. E 7

The material extracted by ether from the mixture of hydrolytic products consisted of a yellowish, partly crystalline, unctuous mass which had an agreeable aromatic odor, somewhat resembling that of nutmeg. Three daily doses of this fraction each containing 10.72 gm., equivalent to 4 pounds per hundredweight, were fed in emulsion to sheep 708 from April 16 to April 18, 1923. On April 19 the animal was unable to stand without trembling. The symptoms of trembles became worse, and the animal died Sunday morning, April 22. By the following day post-mortem change was so advanced that no conclusions could be drawn from autopsy.

The suckling lamb of this ewe, sheep 709, had received the milk from the mother during the feeding and the subsequent disease period. At the beginning of the experiment the lamb was healthy and normal. On April 21, two days after the appearance of trembles in the mother, the lamb also showed symptoms of trembles. These developed rapidly until the lamb was unable to stand. After the death of the mother the lamb was fed cow's milk for several days. During this period no improvement occurred. A specimen of urine was obtained April 26. This was acid and contained acetone. The lamb was also excreting acetone by the lungs. The lamb was killed for autopsy April 28 and the post-mortem examination was immediately made. The liver appeared discolored and the kidneys were degenerated. The other organs appeared to be normal.

This experiment definitely located the toxic principle in the sterol fraction and there arose the problem of separating it from the other sterols present. A portion was submitted to steam distillation, but only a very small quantity of volatile material was obtained. The main portion of the sterol fraction was dissolved in hot 85 per cent alcohol and allowed to cool when a considerable quantity of needleshaped crystals separated out. These were collected by filtration and the filtrate was twice concentrated, each time yielding a crop of the same substance. These crops were united and recrystallized from 85 per cent alcohol, when the substance was obtained pure. 
The mother liquors yielded an impure crop of this substance that was contaminated with oily matter.

The mother liquors from which the crystalline sterol was obtained were concentrated by evaporation, but nothing further could be made to crystallize from them. The solvent was removed and left a viscous, oily residue of aromatic odor. The larger portion was soluble in petroleum ether. The soluble matter was labeled E $7.6 \mathrm{~A}$, the insoluble $\mathrm{E} 7.5 \mathrm{AB}$.

\section{THE CRYSTALLINE STEROL}

The crystalline sterol was a mass of soft, white needles melting at 148 to $149^{\circ} \mathrm{C}$. and soluble in the ordinary organic solvents. Elementary analysis indicates that the formula is $\mathrm{C}_{18} \mathrm{H}_{30} \mathrm{O}$. It does not give the characteristic reactions of phytosterols. A quantity of this substance was emulsified in water with acacia. Four daily doses each containing $1.2 \mathrm{gm}$. of the substance, equivalent to 4 pounds of green plant per hundredweight of sheep, were fed to sheep 779 from July 3 to July 7, 1923, but produced no effect on the animal. A second feeding of this mixture was made between August 28 and September 5 , 1923 , when the same sheep received 6 daily doses of $2.5 \mathrm{gm}$. and one of $2 \mathrm{gm}$., or a total of 54.4 pounds equivalent of green plant. There was no effect from these feedings.

\section{LOT NO. E 9}

A similar fraction from another lot (E 9. AAD), which consisted largely of the sterol, was fed in varying doses from June 24 to July 5 , 1924, to sheep 782. This animal received in all 9 doses containing a total of $33.4 \mathrm{gm}$. of the fraction, equivalent to 63.8 pounds of green plant per hundredweight. There was no effect from this feeding.

These findings showed that the toxic principle was to be sought for in the other two fractions of the original sterol fraction, the portion soluble in petroleum ether, and the small quantity of material insoluble in that solvent.

\section{THE PETROLEUM-ETHER INSOLUBLE FRACTION}

This fraction labeled E 7.5 AB was a thick, brownish noncrystalline mass which weighed $8 \mathrm{gm}$. Nothing crystalline could be prepared from it. It was emulsified in water with acacia and fed in four doses of $1 \mathrm{gm}$. each to sheep 779 from August 2 to August 6, 1923, and in a dose of $3 \mathrm{gm}$. August 14. There was no effect from the feeding.

\section{THE PETROLEUM-ETHER SOLUBLE FRACTION}

The experimental feedings, described above, which showed the lack of toxicity of all other fractions of the original sterol fraction made it evident that E $7.6 \mathrm{~A}$ contained the toxic principle. Efforts were then directed toward separating this fraction into its constituents, which were mainly tremetol, with some crystalline sterol, coloring matters, probably carrotin, and perhaps other unknown substances. A portion of the crystalline sterol was removed by cooling the fraction to a low temperature and filtering it from the separated crystals. Other methods of separation were tried but none were successful, and finally it was decided to distill the fraction under very diminished pressure and to test the distillates. 
Three fractions were obtained, upon vacuum distillation, as follows:

Distillate I, 188 to $192^{\circ}$ C. (15 mm.) $15 \mathrm{gm}$.

Distillate II, 192 to $256^{\circ}$ C. $10 \mathrm{gm}$.

Residue.

The distillates were united and again distilled. Four fractions were obtained as follows:

Distillate I, 166 to $170^{\circ}$ C. $(15 \mathrm{~mm}$.) $5 \mathrm{gm}$. Tremetol test, negative.

Distillate II, 170 to $205^{\circ}$ C. (12 mm.) $10 \mathrm{gm}$. Tremetol test, positive.

Distillate III, 205 to $235^{\circ}$ C. $(12 \mathrm{~mm}$.) $5 \mathrm{gm}$. Tremetol test, negative.

Residue very small.

The temperatures at which the second distillates were obtained indicate that there had been some decomposition during the first distillation.

All the distillates were thick, oily liquids; the higher boiling fraction on cooling deposited a small quantity of crystals.

Distillate II was injected intraperitoneally into three guinea pigs June 14, 1923. Pig No. 236 received 0.2 c. c., pig No. 211 received 0.3 c. c., and pig No. 239 received 0.5 c. c. All were made sick and No. 239 died during the night of June 15-16. The post-mortem examination revealed a considerable yellowing of the liver and pale kidneys, the other organs being normal. Guinea pigs 211 and 236 were depressed for several days but finally recovered.

Four grams of this fraction were mixed with a little cottonseed oil (to facilitate emulsification), emulsified in water with acacia, and fed in four daily doses of $1 \mathrm{gm}$. each to sheep 779 , from July11 to July 14, 1923. There was no effect from this feeding.

A similar distillate from lot E 8 fed to sheep 782 from January 2 to January 5, 1924, in four doses of $1.25 \mathrm{gm}$. each (emulsified) produced no effect on the animal.

The remaining vacuum distillates and the residue obtained in the first distillation were fed separately in large doses to this sheep, but in no case was the animal affected. It seemed likely, therefore, that the toxic substance was altered by the distillation.

A small quantity of the undistilled petroleum-ether-soluble material, calculated to be equivalent to 31.34 pounds of green plant, but probably equivalent to much less on account of various losses incidental to chemical processing, was emulsified and fed to sheep 779 in two doses on September 12 and 13, 1923. This treatment appeared markedly to depress the animal, but no trembling was observed, and the feedings could not be continued on account of lack of material.

\section{TREMETOL}

Fractions E 5. AAB, E 7. 3A, and E 10. AAB, which consisted in part of tremetol and fractions $\mathrm{E} 7.4 \mathrm{~A}$ and $7.5 \mathrm{~A}$, which were impure tremetol, were fed to sheep $625,650,707,5,708$, and 779 . All the sheep were affected and the first five developed characteristic symptoms of trembles; sheep 625 recovered and the remainder died. Sheep 709 , a suckling lamb that received the milk of sheep 708 while the latter was sick with trembles, also developed characteristic symptoms of the poisoning.

Many feeding tests have been made on guinea pigs, but these animals have not reacted in any uniform fashion to the doses given. Highly purified tremetol, from a lot used for chemical analyses and 
molecular-weight determinations, was injected intraperitoneally into 4 guinea pigs July 8, 1926. Pigs 293, 294, 295, and 296 received respectively 0.2 c. c., 0.1 c. c., 0.15 c. c., and 0.3 c. c. All were made sick, pigs 294 and 295 died in 7 days, and the post-mortem examination, ${ }^{4}$ disclosed the nutmeg liver commonly found in trembles cases. The remaining animals that received the larger doses survived. On July 27 these were again injected intraperitoneally, pig 293 receiving 0.25 c. c. and pig 296 receiving $0.3 \mathrm{c}$. c. Both were made sick. Pig 296 showed very severe symptoms, lost considerable weight, and died Áugust 29.

The autopsy revealed emaciation, anemia, and some enlargement of the liver. The urine was acid and contained albumin, but no acetone bodies. At first, pig No. 293 did not appear greatly affected. He became depressed and finally lost weight and was found dead September 15, seven weeks after the last injection. Autopsy showed emaciation, and anemia. The liver was pale and contained several large, yellowish areas, the kidneys were pale, and the spleen was enlarged and dark. There were three small healed ulcers on the mucosa of the ileum. No odor of acetone was present.

The experimental evidence indicates that tremetol is the substance that causes the disease known as trembles in cattle, horses, and sheep. On account of the small quantity of pure tremetol available it was impossible to conduct confirmatory experiments on large animals during this investigation. Final proof of the causal relationship of tremetol to trembles, therefore, must be delayed until such experiments can be carried out. Efforts are in progress to prepare a quantity of pure tremetol for this purpose.

\section{FEEDING OF EXTRACTS THAT DID NOT CONTAIN TREMETOL}

All other constituents of the plant were fed at one time or another to sheep, guinea pigs, rabbits, and cats. The only other constituents of the plant that produced death or symptoms of poisoning were the resin acids and the volatile oil. Several feedings of the resin acids to sheep $6,550,622$, and 679 produced no effect except that in the case of sheep 622 a small but definite depression of the pulse rate was observed. Certainly the resin acids are incapable of producing trembles and probably play no rôle in milk sickness under usual conditions.

The resin acids are, however, toxic to rabbits and guinea pigs, when derived from either green or dried plants.

It is very likely that many of the cases produced in guinea pigs and rabbits in experimental feeding with Eupatorium urticaefolium, green and dried, and with extracts made from it, have been the result of poisoning by the resin acids rather than by tremetol. This would account for the toxicity of the dried plant and its extracts to laboratory animals as reported by several investigators, a fact which seemed contrary to the general experience that dried plant would not produce trembles in cattle and sheep when fed in moderately large doses. Drying the plant apparently does not greatly diminish the toxicity of these resin acids.

None of the remaining constituents of Eupatorium urticaefolium was observed to be harmful to the animals experimented with even in the very large doses sometimes fed.

4. Conducted by W. S. Gochenour, to whom the author wishes to express his appreciation. 


\section{GLUCOSIDES}

Aqueous extracts that contain the glucosidal substance present in richweed fed to several guinea pigs and to sheep 539, 596, 650, and 6 produced no effect on these animals. This fact considered in conjunction with other evidence as to the character of the toxic principle seems to indicate that this glucoside is not toxic and bears no relationship to trembles.

\section{ALKALOIDS}

The basic substances extracted from lot E 2 were fed to sheep 534. The bases were also present in the aqueous extracts fed as described in the preceding paragraph. No evidence of toxicity was obtained as a result of these feedings, and it is apparent that the basic constituents of richweed are not responsible for the toxicity of the plant.

\section{ALUMINUM PHOSPHATE}

No feedings with aluminum phosphate were made. The extensive feeding experiments reported by Wolf, Curtis, and Kaupp (22), the abandonment of the aluminum hypothesis by Moseley (13), who originated it, the absence of anything in the pharmacology of aluminium compounds that supports the hypothesis, and the discovery of an aluminium-free substance that does produce trembles, all obviate the necessity of experimental work with this compound.

\section{DRIED AND GREEN PLANTS}

Lots E 2 and E 8 were specimens of dried Eupatorium urticaefolium that had been collected in the neighborhood of Beecher City, Ill., in 1915, and dried and stored, one for 4 and the other for 8 years before being used in this investigation. No cases of trembles were produced by extracts of these specimens. Eight lots of green plant were used, 4 from Virginia and 4 from Illinois. Of the Virginia collection, 1 was extracted and fed only to guinea pigs, 2 others were fed in substance, and the fourth lot was extracted and fractionated and the fractions fed to sheep. None of these feedings produced cases of trembles. Of the 4 lots of green plant obtained from Illinois, 3 were extracted and produced trembles in sheep; the fourth lot was extracted and fractionated but no cases of trembles were obtained from the feeding of this material. Green plant packed in milk cans and preserved in chloroform water furnished the most active extracts used; other samples of green plant that were mailed to Washington from Illinois as soon as they were collected and which were received within 3 or 4 days and immediately placed in alcohol, were of diminished toxicity.

The color reaction for tremetol has been applied also to specimens of green and dried plants. A sample of the plant collected at the time the material of lot 5 was gathered in Illinois, September, 1920, was shipped in a gunny sack to Washington and was dried in the laboratory. After six years' storage there a portion of it was submitted to the test for tremetol with negative results.

Inasmuch as this plant came from a lot that was very toxic, as demonstrated by feeding tests, the failure to get a positive test for tremetol is quite conclusive evidence that drying destroys this toxic principle. Another sample of dried plant, collected at Woodmont, Va., in June, 1921, and immediately dried in the shade, was tested 
after five years' storage in the laboratory. This sample was also negative when tested for tremetol.

Specimens of fresh plant from Arlington County, Va., were tested during the summer of 1926 . Several plants collected at different times at one place in Woodmont reacted positively to the tremetol test. A number of other specimens, collected at a point about onehalf mile from the first lot, and at different times, gave either a faint or a quite negative reaction to the tremetol test.

\section{MILK SICKNESS, TREMBLES, AND ACIDOSIS}

Since the first publication on milk sickness by Drake (4) reference has been repeatedly made to a peculiar odor on the breath and eructations of milk-sickness patients and animals with trembles, and to the marked odor observed about corpses and carcasses of victims of the poisoning.

Drake says, "The breath is peculiarly disgusting, even loathsome," and in fact this symptom so uniformly accompanied the malady that it was considered pathognomonic by many physicians.

Walsh (20) suspecting that the foul odor was due to the excretion of acetone by the lungs and recognizing the similarity between certain symptoms of milk sickness and diabetes, diagnosed human milk sickness as acidosis and tested for acetone in the urine. This ketone was found in several specimens.

Jordan and Harris (9), who were in consultation with Walsh, obtained specimens of urine from his cases. In two of these specimens acetone was detected; in a third, taken from a mild case from which the patient had previously recovered, no acetone was detected.

From one of the positive urines R. T. Woodyatt, of the University of Chicago, was able to isolate acetone and identify it by means of the paranitrophenylhydrazone.

Walsh (21) has reported additional cases of milk sickness in which acidosis was observed.

In the course of the present study a great deal of evidence has been obtained which demonstrates conclusively that an acidosis accompanies Eupatorium poisoning. The odor of acetone has been observed on the breath of each sheep that was trembling and in all such cases in which a test was made the presence of acetone in the urine was demonstrated. In a few cases, acetone was tested for and demonstrated in the blood. Inasmuch as symptoms of severe poisoning appear at least 24 hours before acetone may be detected in the urine or on the breath, it seems that the acidosis is a consequence of the poisoning and not one of the casual factors.

The results obtained in the examinations for acetone are presented in Table 5.

TABLE 5.-Excretion of acetone by sheep poisoned by richweed

\begin{tabular}{|c|c|c|c|c|c|}
\hline $\begin{array}{c}\text { Sheep } \\
\text { No. }\end{array}$ & $\begin{array}{l}\text { Date of } \\
\text { trembling }\end{array}$ & $\begin{array}{c}\text { Date acetone } \\
\text { appeared on } \\
\text { breath }\end{array}$ & $\begin{array}{l}\text { Date acetone } \\
\text { was found a } \\
\text { in urine }\end{array}$ & Acetone in blood & $\begin{array}{l}\text { Termination of } \\
\text { sickness }\end{array}$ \\
\hline 625 & Sept. 4,1921 & Sept. 6,1921 & Sept. 6,1921 & Not tested for & Recovered. \\
\hline 650 & Sept. 13,1921 & Sept. 15,1921 & Sept. 15,1921 & Present & $\begin{array}{l}\text { Killed for autopsy, } \\
\text { Sept. } 19,1921 \text {. }\end{array}$ \\
\hline 709 & Apr. 21,1923 & Not noted. & Apr. 26,1923 & Not tested for & Killed for autopsy. \\
\hline 5 & A pr. 16,1926 & Apr. 17,1926 & Apr. 17,1926 & Present & Died A pr. 22, 1926. \\
\hline
\end{tabular}

a In larger amounts than traces. 
The effect on the blood-sugar concentration is shown in the case of sheep 5 whose normal blood-sugar content was 0.104 gm. per 100 c. c. On the day when the first trembling was noted the blood sugar had risen to $0.168 \mathrm{gm}$. This was followed by a fall to $0.138 \mathrm{gm}$. six days later, due probably to the fact that feeding with the Eupatorium extract was discontinued as soon as symptoms of trembling appeared and remedial measures were begun.

\section{CONCLUSIONS}

The chemical and pharmacological data indicate that the constituent of Eupatorium urticaefolium which is responsible for trembles is tremetol, $\mathrm{C}_{16} \mathrm{H}_{22} \mathrm{O}_{3}$. Tremetol has the properties of an unsaturated alcohol and is soluble in fats and fat solvents. It may be secreted in milk and would be found in butter made from such milk.

When tremetol is dissolved in petroleum ether and the solution is floated on the surface of sulphuric acid, a characteristic red color is produced.

A volatile oil and a resin acid are also present in this plant. Neither of these is capable of producing trembles in sheep. The resin acid is toxic to rabbits and guinea pigs. Small doses of the volatile oil appear harmless, but larger doses are dangerous.

Other constituents of the plant include fatty acids, especially acetic acid; a crystalline sterol, $\mathrm{C}_{18} \mathrm{H}_{30} \mathrm{O}$, melting at $148-9^{\circ} \mathrm{C}$.; inulin; levulose; an organic base; and a nontoxic glucoside.

When richweed is dried the tremetol content rapidly diminishes and when completely dry the plant is incapable of producing trembles. The dried plant, however, still contains the toxic resin acid and the volatile oil.

Sheep poisoned by richweed or by tremetol develop an acidosis and excrete acetone through lungs and kidneys. The sugar content of the blood is markedly increased. Guinea pigs that were poisoned by the dry plant, with the resin acid, or tremetol, were not observed to excrete acetone.

(1) Bukey, F. S.

\section{LITERATURE CITED}

1925. A PARTIAL ANALYSIS OF THE FRUIT OF EUPATORIUM URTICEFOLIUM. Jour. Amer. Pharm. Assoc. 14: 595-599.

(2) Crawford, A. C.

1908. THE SUPPOSED RELATIONSHip OF White SNAKERoot To MILKSickness, or "Trembles." U. S. Dept. Agr., Bur. Plant Indus. Bul. 121: 5-20, illus.

(3) Curtis, R. S., and Wolf, F. A.

1917. eupatorium ageratoides, the cause of trembles. Jour. Agr.

(4) Drake, D. Research 9: 397-404, illus.

1810. Notices CONCERning Cincinnati. $60 \mathrm{p}$. Cincinnati. (Reprint in Quart. Pub. Hist. and Phil. Soc. Ohio, v. 3, no. 1-2, 1908.)

1815. NATURAL AND Statistical View, OR PiCtURE OF CINCINNATi AND

(6) Anonymous. THE Miami Country. $251 \mathrm{p}$, illus. Cincinnati.

1811. [MiLK sickness.] Liberty Hall 7 (321): [1]. Reprinted in Med. Repository [New York] 15: 92-94. 1912.

(7) Jordan, C. B., Whelan, J. P., and Gidley, W. F.

1924. A STUDY OF THE CAUSE OF TREMBLES (IN DOMESTIC ANIMALS) AND Milksickness (IN Man). Jour. Amer. Pharm. Assoc. 13: 206210. 
(8) Jordan, E. O., and HARRIS, N. M.

1908. The CAUSe of MILKsickness or trembles. Jour. Amer. Med. Assoc. 50: 1665-1673.

(9) and Harris, N. M.

1909. MILKSICKNess. Jour. Infect. Diseases 6: 401-491, illus.

(10) LUCKHARDT, A. B.

1909. ADDITIONAL NOTES ON THE BACTERIOLOGY AND PATHOLOGY OF MILKSICKNess. Jour. Infect. Diseases 6: 492-505, illus.

(11) McCoy, G. W.

1908. MILK sickness. U. S. Hyg. Lab. Bul. 41: 211-219.

(12) Marsh, C. D., and Clawson, A. B.

1917. e UPatorium URticaefolium as a poisonous plant. Jour. Agr. Research 11: 699-716, illus.

(13) Moseley, E. L.

1906. THE CAUSE OF TREMBLES IN CATTLE, SHEEP AND HORSES AND OF MILK-SICKNESS IN PEOPLE. Ohio Nat. 6: 463-470, 477-483.

(14) 1909 . The CAUSe of trembles ANd milksickness. Med. Rec. 75 :

(15)

1910. ANTIDote For ALUMinUm Phosphate, The POISON That CAUSES MILK-SICKNESS. Med. Rec. 77: 620-622.

1917. MILK-SICKNESS AND TREMBLES CAUSED BY RESIN OF WHITE SNAKeroot. Med. Rec. 92: 428-429.

(17) Nicolay, J. G., and Hay, J.

1890. ABRAHAM LINCOLN, A history. v. 1, illus. New York.

(18) Pammel, L. H.

1923. MILK SICKNESS OR TREMBLES CAUSED BY WHITE SNAKE ROOT.

(19) Sackett, W. G.

Vet. Med. 18: 437-438, 440.

1919. THE CONNECTION OF MILKSICKNESS WITH THE POISONOUS QUALITIES OF WHITE SNAKE-ROOT (EUPATORIUM URTICAEFOLIUM).

(20) Walsh, W. E. Jour. Infect. Diseases 24: 231-259.

1909. CLINICAL REPORT OF THE REAPPEARANCE OF THE ONCE COMMON AND FATAL MILK SICKNESS OR "MILKSICK," WITH SUCCESSFUL RATIONAL TREATMENT DEDUCTED FROM CLINICAL FINDINGS. Ill. Med. Jour. 15: 422-425.

(21) - 1926. "MILK sick," or white snakeroot poisoning. Jour. Amer. Med. Assoc. 87: 555-556.

(22) Wolf, F. A., Curtis, R. S., and Kaupp, B. F.

1918. A MONOGRAPH ON TREMBLES OR MILKSICKNESS AND WHITE snake root. N. C. Agr. Expt. Sta. Tech. Bul. 15, 74 p., illus 




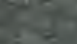

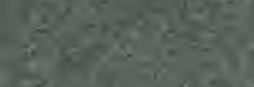

\section{i.}

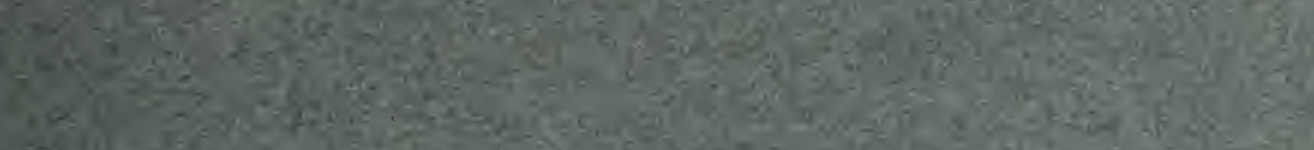

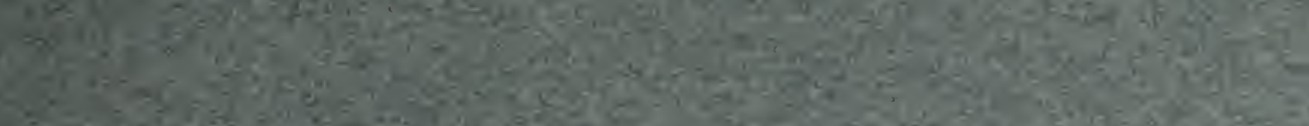

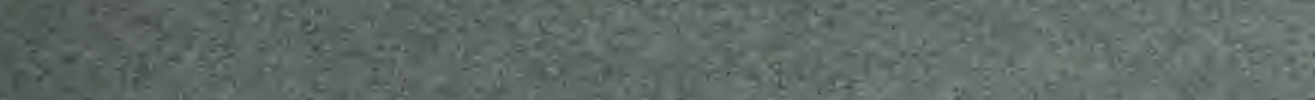
Wyi

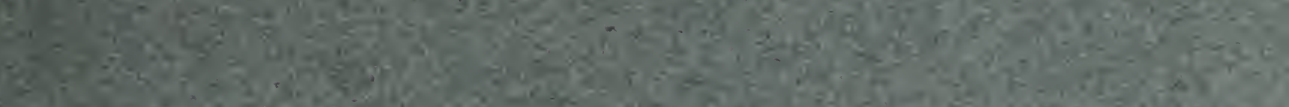

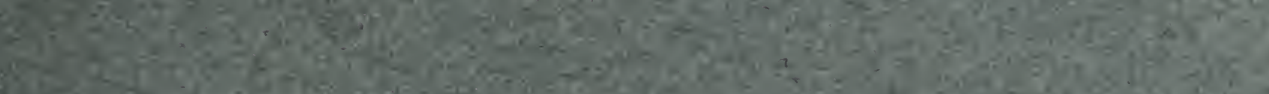

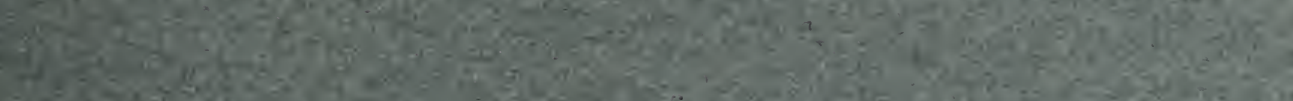

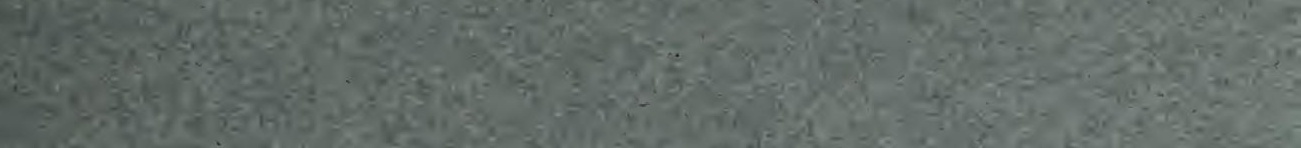

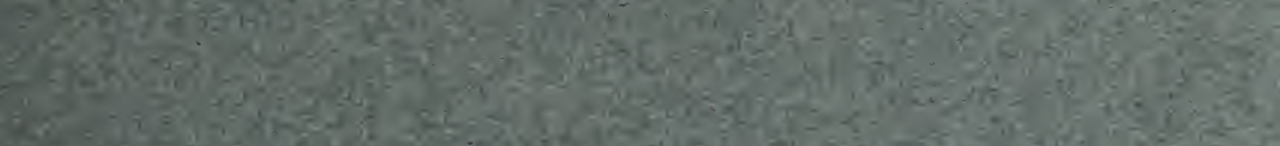

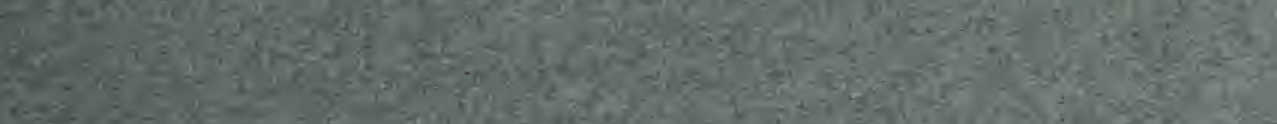
er.

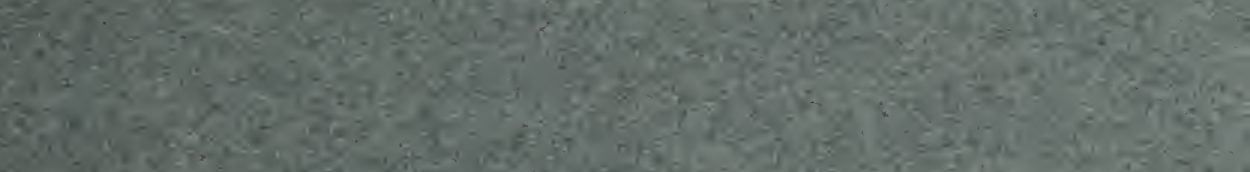

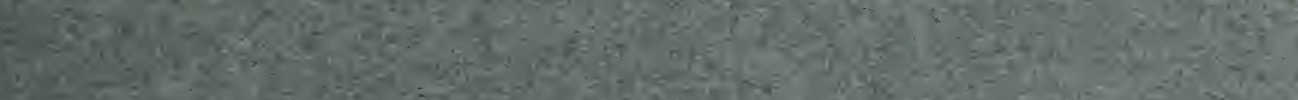

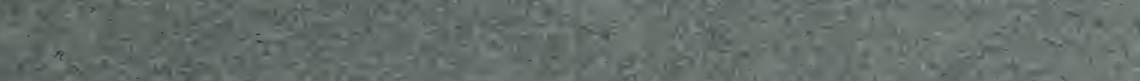

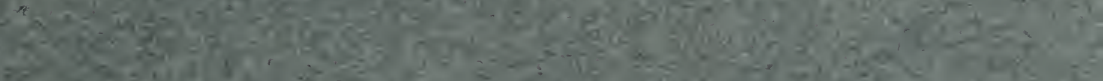

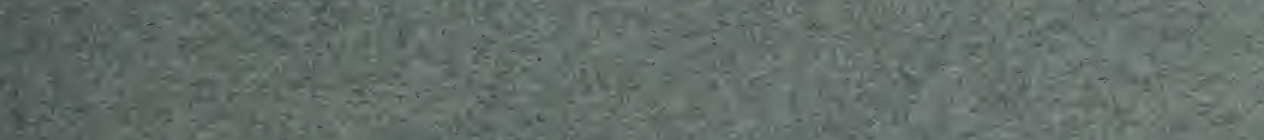
(2) $3 x$ H.

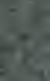

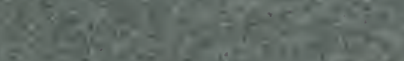
(45.

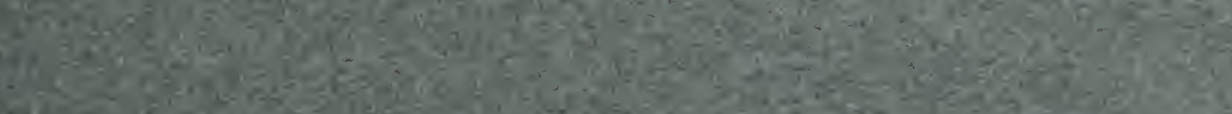
W'

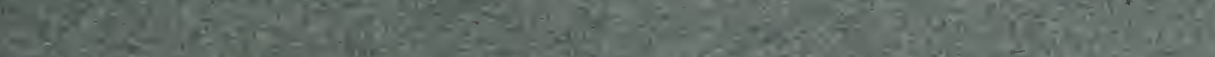

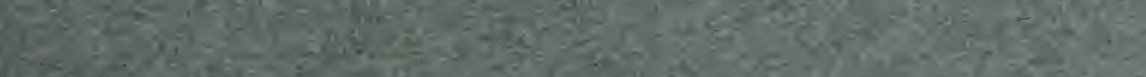

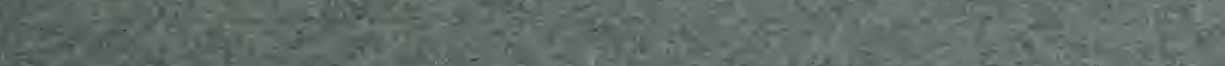

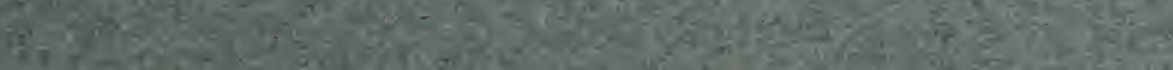

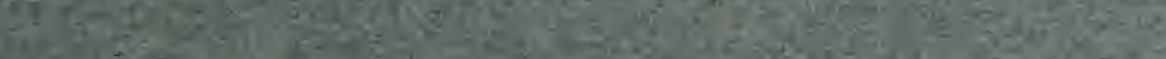

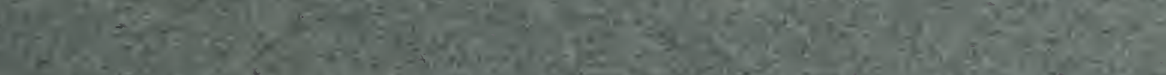

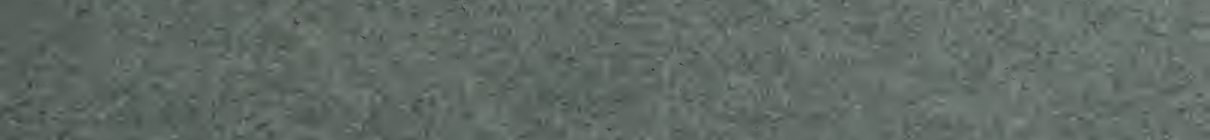

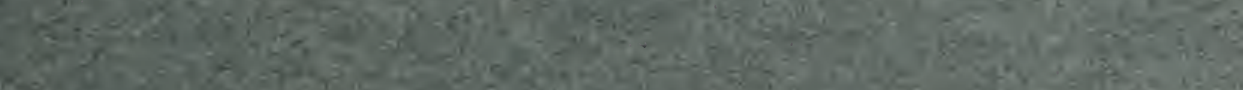

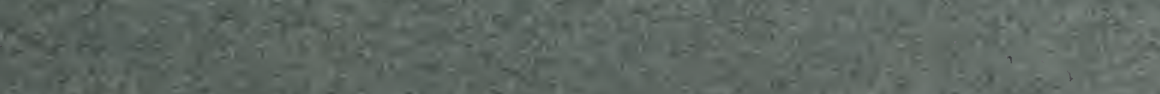

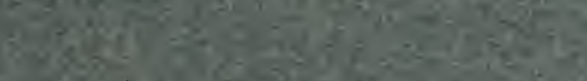

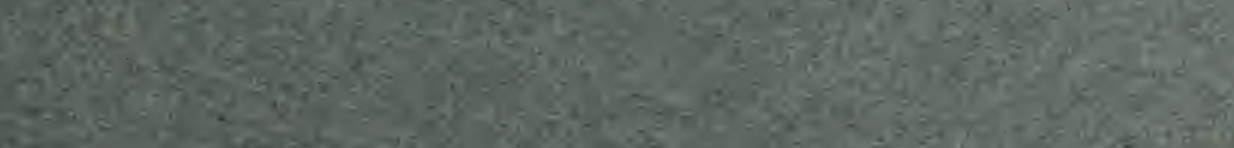

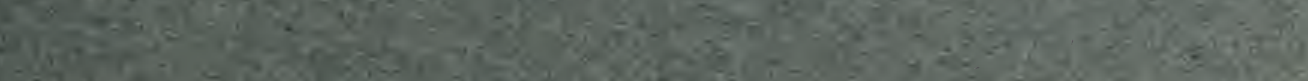

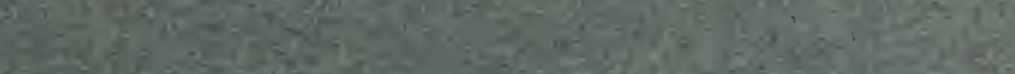

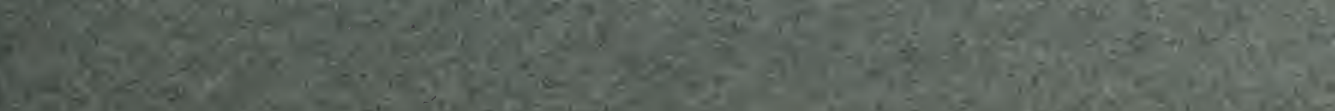


